Provided for non-commercial research and education use. Not for reproduction, distribution or commercial use.

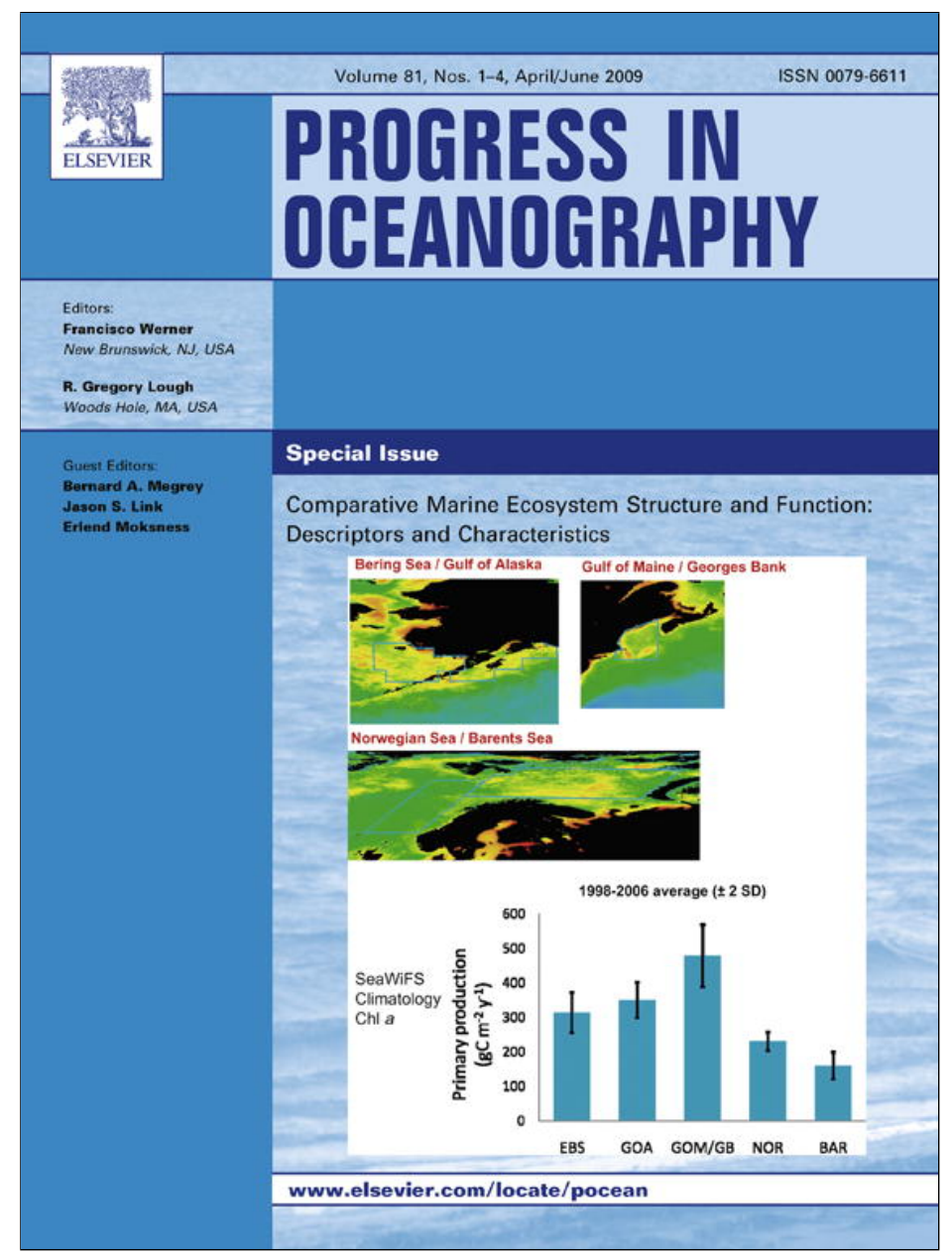

This article appeared in a journal published by Elsevier. The attached copy is furnished to the author for internal non-commercial research and education use, including for instruction at the authors institution and sharing with colleagues.

Other uses, including reproduction and distribution, or selling or licensing copies, or posting to personal, institutional or third party websites are prohibited.

In most cases authors are permitted to post their version of the article (e.g. in Word or Tex form) to their personal website or institutional repository. Authors requiring further information regarding Elsevier's archiving and manuscript policies are encouraged to visit:

http://www.elsevier.com/copyright 


\title{
Ecosystem exploitation and trophodynamic indicators: A comparison between the Northern Adriatic Sea and Southern New England
}

\author{
Fabio Pranovi ${ }^{\mathrm{a}, *}$, Jason S. Link ${ }^{\mathrm{b}}$ \\ ${ }^{a}$ Dipartimento di Scienze Ambientali, Università di Venezia, Castello 2737/B, 30170 Venezia, Italy \\ ${ }^{\mathrm{b}}$ NOAA, National Marine Fisheries Service, Northeast Fisheries Science Center, Woods Hole, MA 02543, USA
}

\section{A R T I C L E I N F O}

Available online 8 April 2009

\begin{abstract}
A B S T R A C T
In an ecosystem-based resource management context, it is crucial to assess the relationships between community structure and ecosystem function and how those relationships change with resource extraction. To elucidate how changes in resource use can affect community structure and ecosystem function, we executed a comparative analysis of two different ecosystems subjected to notable fishing pressure. We contrasted the Northern Adriatic Sea (NAS) and Southern New England (SNE) ecosystems by examining outputs from comparable steady-state models. Both ecosystems have relatively high fishing pressure and a high biomass of benthic invertebrates. The basic structure of the food webs shows differences both in the number and definition of the functional groups, as described in the models. Fisheries, on the contrary, show similarities both in terms of catches and discards. Almost all statistics summarizing the structure and flows showed values three times higher in the SNE than in the NAS ecosystem, but despite this difference the two ecosystems exhibited similar, overall properties. Biomass ratios and the Mixed Trophic Impact (MTI) analysis showed that both ecosystems are dominated by the benthic compartment. Removing the biomass effect, however, shows a clear top-down effect, with a high rank achieved by fishing activities. In general terms, the low mean trophic level of catches and the high primary production required (PPR) values result in a high overexploitation level of the ecosystem, as highlighted by the $L$ index. We conclude by exploring how comparative studies will continue to be valuable as ecosystem-based management is further implemented.
\end{abstract}

(c) 2009 Elsevier Ltd. All rights reserved.

\section{Introduction}

The ecosystem approach to natural resource management has been espoused (WSSD, 2002; FAO, 2003) and, at present, is recommended for adoption as a major policy initiative in Europe, the US, and elsewhere including the EU Water Framework Directive, Common Fisheries Policy and the European Marine Strategy (CBD, 2004; USOC, 2004; FAO, 2003). The aim of the new approach is to ensure that the planning, development and management of the environment will meet social and economic needs without jeopardizing options for future generations to benefit from the full range of goods and services provided by marine ecosystems; i.e. to ensure sustainable development (FAO, 2003; Pickitch et al., 2004). In this context, ecosystem-based management (EBM) aims to conserve the structure and function of ecosystems in order to maintain ecosystem services (CBD, 2004).

One of the main challenges for EBM is the implementation of this more holistic approach, in which the ecosystem represents the management unit (Raffaelli, 2006). Ecosystem considerations

\footnotetext{
* Corresponding author. Tel.: +39 412347735; fax: +39 415281494.

E-mail addresses: fpranovi@unive.it (F. Pranovi), jason.link@noaa.gov (J.S. Link).
}

in a marine scientific and management context have been extant for more than a century (e.g. Baird, 1873), but how to make them operational has remained a key challenge. Research needs to be extended to encompass not only the structures of the ecosystem (classically studied components such as populations, species, communities, habitats) but also the processes related to the functioning of the ecological systems (production, consumption, respiration, energy flow and cycling). Ultimately, we need to seek general relationships among patterns and processes at multiple spatial scales (e.g. Zajac, 1999; Hyrenbach et al., 2000).

The relationship between marine ecosystem structure and function has become increasingly prominent in the last decade (Duffy, 2006; Raffaelli, 2006). Yet moving from knowledge of ecosystem structure and function to understanding the relationships between them has been more challenging. Shifting from the assessment of the human-use effects on ecosystem structure towards the assessment of the modifications that these structural changes induce in the processes of perturbed ecosystems requires caution due to the uncertainty, long feedback times and highly nonlinear ecosystem responses to external perturbations (Holling et al., 1995). For example, understanding how changes in biodiversity affect ecosystem function requires integrating diversity within trophic levels 
(horizontal diversity) and across trophic levels (vertical diversity; including food chain length and omnivory). As another example, the relative importance of top-down or bottom-up trophic controls in continental shelf ecosystems has important implications for how ecosystems respond to perturbations (e.g. Frank et al., 2007). The need to improve our knowledge about the relationships between structure and function is critical for adopting effective EBM strategies and policies.

One way to facilitate a better understanding of the relationship between ecosystem structure and function (and responses to perturbations thereupon) is to engage in comparative ecosystem studies (Hunt and Megrey, 2005; Moloney et al., 2005; Coll et al., 2007). Comparison between similar or comparable ecosystems (i.e. systems with similar latitudinal location and characterized by similar environmental features/constraints) is a useful analytical approach which can allow us to better understand the mechanisms which drive the functioning of ecological systems. In comparable ecosystems, some features will be shared but others will be unique, and analysis of these similar and contrasting patterns and processes can reveal important drivers in each ecosystem. These comparative analyses provide an opportunity for taking a broader ecosystem perspective and permit the ability to draw generalizations important to successful implementation of EBM.

To better elucidate key marine ecosystem properties and to facilitate implementation of EBM, we examined two comparable marine ecosystems; the Northern Adriatic Sea (NAS) and Southern New England (SNE). The reason we chose the NAS and SNE ecosystems are that they both represent relatively shallow, continental shelf ecosystems with a high benthic biomass. Additionally, both have had a notable history of extracting living marine resources, share some physio-chemical features, and have had enough scientific studies to generate adequate databases required for this study. Our objectives in this work were to present summaries of systemic metrics from both ecosystems and to compare those metrics between the two ecosystems.

\section{Material and methods}

\subsection{Ecosystem and model descriptions}

The upper portion of the Adriatic Sea (NAS) (Fig. 1) constitutes the widest continental shelf in the Mediterranean Sea and, in the context of the generally oligotrophic conditions of the basin, represents a unique habitat (Pinardi et al., 2006). The NAS is a shallow $\left(<35 \mathrm{~m}\right.$ ) semi-enclosed basin $\left(14,178 \mathrm{~km}^{2}\right)$, characterized by strong riverine outflows, mainly from the Po River, with high loads of organic matter and nutrients (Revelante and Gilmartin, 1983; Turley, 1999). The NAS is influenced by strong winds in winter causing mixing of the water column and calm summer conditions causing stratification, with occurrence of recurrent eutrophication and the production of mucillagenous aggregates (Malanotte Rizzoli and Bergamasco, 1983; Artegiani et al., 1997a,b). It can be considered as a homogeneous system characterized by the presence of incoherent sediments, mainly mud and relict sand, and by a high level of productivity (Fonda Umani et al., 1992). In relation to climatic and hydrographic features, the basin has been described as the 'Northern Adriatic lacuna', an area more similar to the Atlantic than to the Mediterranean Sea. For instance, the NAS hosts species typical of the cold Atlantic waters (e.g. the brown algae Fucus virsoides J. Agardh - a key species in defining a facies of the intertidal horizon (Pérès and Picard, 1964; Gamulin-Brida, 1974) - and the sprat, Sprattus sprattus). Relatively speaking, the ecosystem structure is dominated by the benthic component, with high standing stocks of biomass sequestered particularly in molluscs (Table 1).

As the NAS is effectively a flat trawlable platform, it is the most exploited Italian basin with more than $15 \%$ of the national fishing fleet operating in the area (Bombace, 2002). The most widespread fishing activities target demersal fish and shellfish. The fleet is composed of otter trawls, "rapido" trawls (a sort of beam trawl gear, rigged with $10 \mathrm{~cm}$ long iron teeth; for further details see Giovanardi et al., 1998), hydraulic dredges, and mid-water trawls

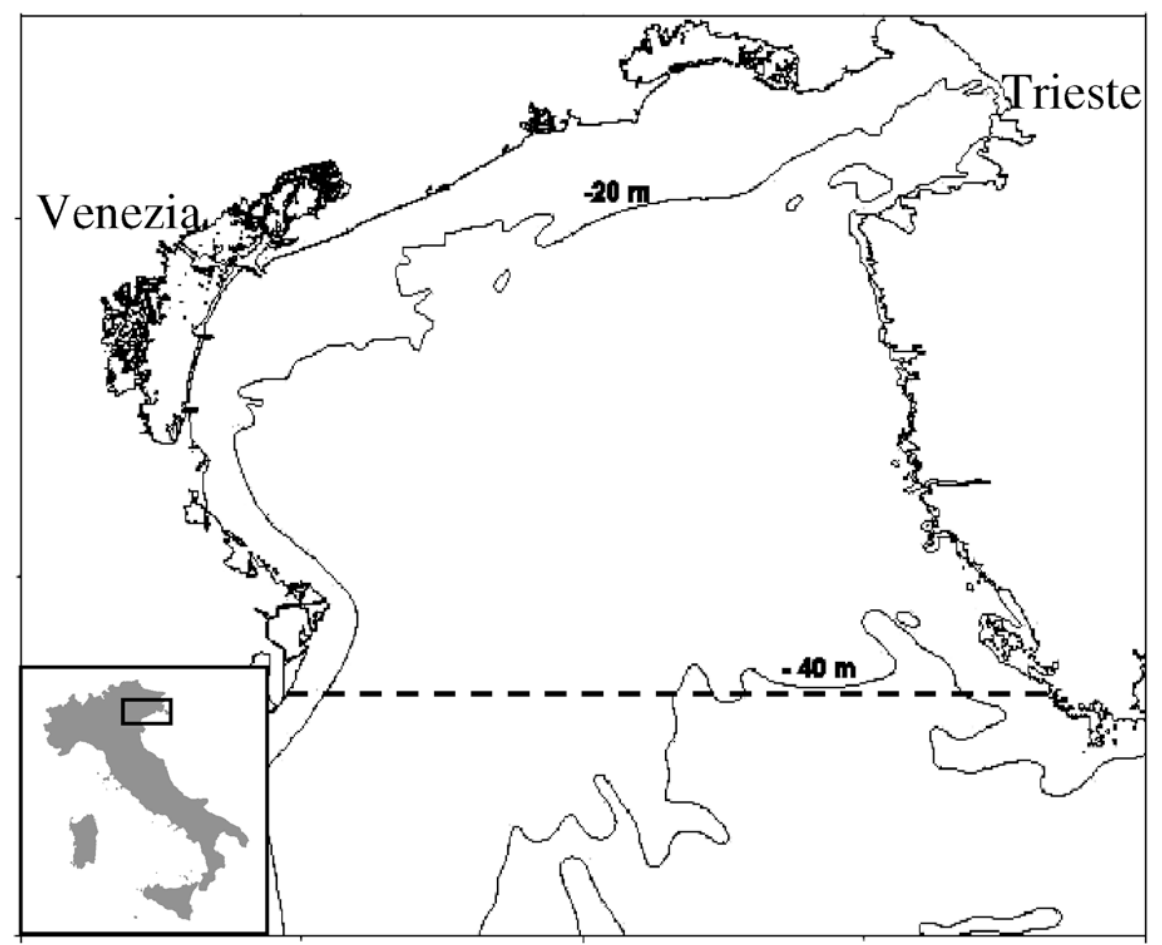

Fig. 1. Northern Adriatic Sea; the southern boundary of the studied area is noted by the dashed line. 
Table 1

Inputs of the Northern Adriatic Sea model. TL, trophic level; $B$, biomass; $P / B$, Production/biomass ratio; $Q / B$, consumption/biomass ratio; EE, ecotrophic efficiency; $P / Q$, production/ consumption ratio or gross efficiency. See Appendix A for further details.

\begin{tabular}{|c|c|c|c|c|c|c|}
\hline Group & $\mathrm{TL}$ & $B\left(\mathrm{t} \mathrm{km}^{-2}\right)$ & $P / B\left(\mathrm{yr}^{-1}\right)$ & $Q / B\left(\mathrm{yr}^{-1}\right)$ & $\mathrm{EE}$ & $P / Q$ \\
\hline Phytoplankton & 1 & 8.4 & 152.133 & - & 0.751 & - \\
\hline Bacterioplankton & 2.1 & 2.138 & 34.348 & 171.742 & 0.908 & 0.2 \\
\hline Microzooplankton & 2.03 & 1.758 & 219 & 438 & 0.215 & 0.5 \\
\hline Zooplankton & 2.35 & 1.456 & 18.25 & 91.25 & 0.825 & 0.2 \\
\hline Meiobenthos & 2.01 & 5.311 & 13.704 & 68.52 & 0.681 & 0.2 \\
\hline Macrobenthos herbivorous & 2.05 & 2.086 & 1.746 & 8.732 & 0.764 & 0.2 \\
\hline Macrobenthos omnivorous & 2.77 & 3.118 & 2.313 & 11.564 & 0.694 & 0.2 \\
\hline Macrobenthos detritivorous & 2.2 & 22.834 & 1.692 & 8.458 & 0.919 & 0.2 \\
\hline Macrobenthos filter feeders & 2.44 & 19.642 & 1.07 & 5.351 & 0.386 & 0.2 \\
\hline Scallops (Pectinidae) & 2.44 & 0.756 & 0.7 & 3.5 & 0.633 & 0.2 \\
\hline Clams (Veneridae) & 2.44 & 1.397 & 1.41 & 7.05 & 0.574 & 0.2 \\
\hline Macrobenthos predator & 2.78 & 7.033 & 1.5 & 7.5 & 0.291 & 0.2 \\
\hline Planctivorous fish & 2.46 & 19.996 & 1.295 & 3.882 & 0.027 & 0.334 \\
\hline Cephalopds & 3.53 & 0.35 & 1.45 & 4.833 & 0.285 & 0.3 \\
\hline Benthic feeders & 3.33 & 0.229 & 1.895 & 5.935 & 0.174 & 0.319 \\
\hline Flat fish & 3.32 & 0.151 & 0.98 & 4.9 & 0.211 & 0.2 \\
\hline Necton feeders & 3.97 & 0.012 & 1.16 & 4.34 & 0.852 & 0.267 \\
\hline Carcasses & 1 & 1 & - & - & 0.3 & - \\
\hline Organic matter & 1 & 183.884 & - & - & 0.53 & - \\
\hline Detritus & 1 & 2 & - & - & 0.687 & - \\
\hline
\end{tabular}

(ICRAM, 2006). The port of Chioggia, located in the Southern part of the Venice lagoon, hosts the most important fishing fleet of the basin, containing $90 \%$ of the fishing boats for this region. Therefore, landings from the Chioggia fleet can be considered as largely representative of the studied area (ICRAM, 2006).

The Southern New England (SNE) ecosystem (Fig. 2) is a continental shelf ecosystem of the North-western Atlantic with an average depth of $60 \mathrm{~m}$, being relatively open and influenced by major flow fields. It covers a total area of $64,060 \mathrm{~km}^{2}$ and has a substrate predominately of fine-grained sand (Poppe et al., 2003). Water flows in the SNE shelf are primarily northwest to southeast, with sources from Arctic waters along the shelf-slope and from the Gulf of Maine (via the Great South Channel). The Gulf Stream Current (GSC) is offshore of the SNE and, unlike Georges Bank, warm-water GSC water does not typically become entrained onto the SNE shelf.

The SNE is a highly productive ecosystem, with total primary production on the order of $1.0 \mathrm{~g} \mathrm{C} \mathrm{m}^{-2} \mathrm{~d}^{-1}$, with annual estimates ranging from 3700 to $4500 \mathrm{~g} \mathrm{~m}^{-2} \mathrm{yr}^{-1}$ for total standing biomass (O'Reilly and Zetlin, 1998; Link et al., 2006). As in the NAS, a high fraction of biomass is sequestered in the benthos, with an important role played by bivalve molluscs (Table 2; Link et al., 2006).

The fisheries operating in the SNE are primarily focused on benthic filter feeders (i.e. scallops), flatfish (several pleuronectids), squids and migratory small pelagics (herring, mackerel and butter-

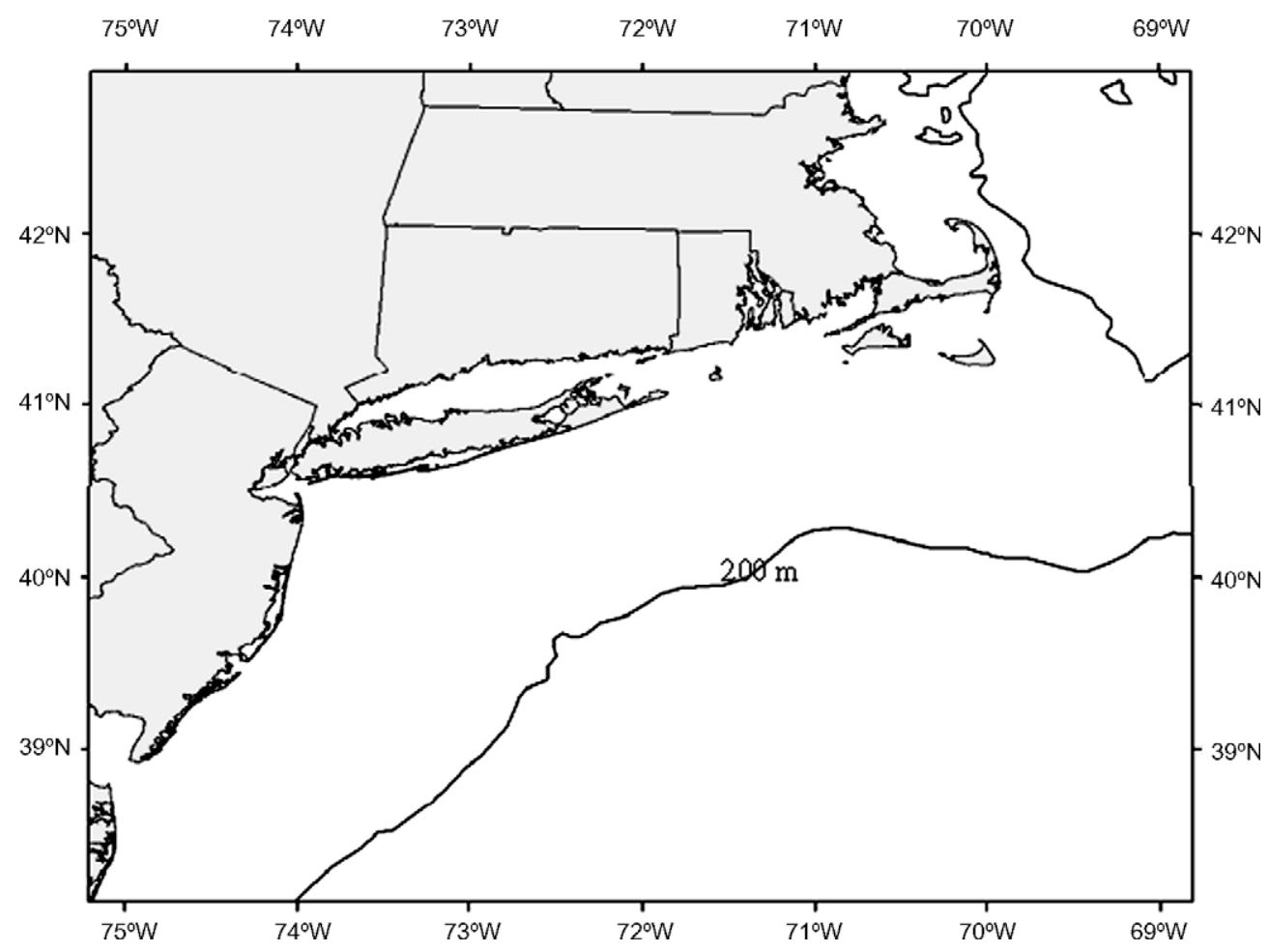

Fig. 2. Southern New England. 
Table 2

Inputs of the Southern New England model. TL, trophic level; $B$, biomass; $P / B$, Production/biomass ratio; $Q / B$, consumption/biomass ratio; EE, ecotrophic efficiency; $P / Q$ production/consumption ratio or gross efficiency. See Link et al. (2006) for further details.

\begin{tabular}{|c|c|c|c|c|c|c|}
\hline Group & $\mathrm{TL}$ & $B\left(\mathrm{t} \mathrm{km}^{-2}\right)$ & $P / B\left(\mathrm{yr}^{-1}\right)$ & $Q / B\left(\mathrm{yr}^{-1}\right)$ & $\mathrm{EE}$ & $P / Q$ \\
\hline Phytoplankton - primary producers & 1 & 26.528 & 182.859 & - & 0.522 & - \\
\hline Bacteria & 2 & 7.532 & 91.25 & 380.208 & 0.9 & 0.24 \\
\hline Microzooplankton & 2.39 & 5.083 & 72 & 242.424 & 0.9 & 0.297 \\
\hline Small copepods & 2.23 & 11.825 & 45.432 & 127.75 & 0.9 & 0.356 \\
\hline Large copepods & 2.66 & 5.653 & 61.986 & 109.5 & 0.9 & 0.566 \\
\hline Gelatinous zooplankton & 3.35 & 1.196 & 40 & 146 & 0.9 & 0.274 \\
\hline Micronekton & 2.81 & 4.233 & 14.25 & 139.286 & 0.776 & 0.102 \\
\hline Mesopelagics & 3.38 & 0.228 & 0.95 & 1.825 & 0.828 & 0.521 \\
\hline Macrobenthos - polychaetes & 2.39 & 35.436 & 2.5 & 17.5 & 0.897 & 0.143 \\
\hline Macrobenthos - crustaceans & 2.59 & 6.392 & 3 & 21 & 0.897 & 0.143 \\
\hline Macrobenthos - molluscs & 2.25 & 17.805 & 2 & 14 & 0.899 & 0.143 \\
\hline Macrobenthos - other & 2.44 & 18.933 & 2.04 & 17.64 & 0.895 & 0.116 \\
\hline Megabenthos - filterers & 2.2 & 3.702 & 5 & 19 & 0.731 & 0.263 \\
\hline Megabenthos - other & 3 & 3.373 & 2 & 16.941 & 0.899 & 0.118 \\
\hline Shrimp et al. & 2.69 & 0.27 & 2 & 5 & 0.878 & 0.4 \\
\hline Larval-juv fish - all & 3.28 & 0.422 & 21 & 45 & 0.592 & 0.467 \\
\hline Small pelagics - commercial & 3.71 & 14.851 & 0.363 & 2 & 0.788 & 0.182 \\
\hline Small pelagics - other & 3.51 & 1.946 & 0.95 & 2 & 0.902 & 0.475 \\
\hline Small pelagics - squid & 3.92 & 3.07 & 0.95 & 2.75 & 0.749 & 0.346 \\
\hline Small pelagics - anadromous & 3.61 & 0.659 & 0.459 & 2 & 0.925 & 0.229 \\
\hline Medium pelagics - piscivores and other & 4.63 & 0.35 & 0.585 & 1.428 & 0.907 & 0.41 \\
\hline Demersals - benthivores & 3.83 & 2.337 & 0.45 & 0.9 & 0.79 & 0.5 \\
\hline Demersals - omnivores & 3.57 & 3.635 & 0.45 & 0.8 & 0.884 & 0.563 \\
\hline Demersals - piscivores & 4.33 & 2.334 & 0.468 & 1.035 & 0.91 & 0.452 \\
\hline Sharks - coastal & 4.58 & 0.0215 & 0.102 & 0.876 & 0.842 & 0.116 \\
\hline Sharks - pelagics & 4.74 & 0.0388 & 0.105 & 0.408 & 0.855 & 0.258 \\
\hline HMS & 4.57 & 0.00548 & 0.584 & 7.289 & 0.832 & 0.08 \\
\hline Pinnipeds & 4.65 & 0.0178 & 0.106 & 8.778 & 0.581 & 0.012 \\
\hline Baleen whales & 3.74 & 0.14 & 0.041 & 4.49 & 0.068 & 0.009 \\
\hline Odontocetes & 4.71 & 0.0752 & 0.041 & 15.641 & 0.793 & 0.003 \\
\hline Sea birds & 4.17 & 0.0107 & 0.275 & 9.952 & 0.746 & 0.028 \\
\hline Discard & 1 & 0.974 & - & - & 0.218 & - \\
\hline Detritus-POC & 1 & 40 & - & - & 0.836 & - \\
\hline
\end{tabular}

fish) (Link et al., 2006). Several gears are utilized, but predominately scallop dredges are used, followed by mid-water trawls and bottom-tending otter trawls.

A mass-balance model was applied to both ecosystems using Ecopath with Ecosim (EwE 5.1; Christensen and Pauly, 1992; Walters et al., 1997), which allows for quantifying and balancing energy flows among the different components of an ecosystem.

The NAS model, representing the ecosystem in 1997-2000, is comprised of 20 nodes, ranging from phytoplankton and bacteria to piscivorous fish (Table 1). The input data were obtained by consulting both the published and unpublished literature; references and further details are reported in Appendix A.

The SNE model, representing the ecosystem in 1996-2000, is comprised of 33 nodes, ranging from phytoplankton and bacteria to whales and highly migratory species (Table 2 ). The energy budget balancing protocols, input data sources and vital rate parameter estimating methodologies are documented more thoroughly elsewhere (Link et al., 2006). Although the source model used both Ecopath and Econetwork, the results used here for our comparisons are based on the balanced Ecopath model.

\subsection{System comparisons}

Due to geographical and oceanographic features, choices during model construction, taxonomic emphasis and data availability, the two models were obviously different in structure, with a different degree of aggregation throughout the food web (Tables 1 and 2). In order to reduce these differences and to make the two systems more comparable, the functional groups have been aggregated according to the scheme noted in Table 3 . First, we distinguished between invertebrate and vertebrate organisms; then we identified the main ecological functional groups; and finally we divided the groups targeted by fishing activities according to benthic invertebrates, demersal and pelagic fish (Table 3 ).

\subsection{Metrics}

To compare the structure and function of the two ecosystems a set of ecological indices based on biomass ratios, trophic flow analysis, thermodynamic concepts, information theory and associated indicators were examined (Christensen et al., 2004; Christensen and Walters, 2004; Cury et al., 2005; Link, 2005). These were calculated based upon the aggregate, comparable food webs for both ecosystems (Table 3).

We calculated and present a series of production (P), biomass (B) and ratios thereof for several compartments of both models. These metrics not only provide a sense of the differences in structure between the two ecosystems, but also serve as proxies for the ecosystem functioning (Link, 2005). We also calculate a series of ratios of fisheries catches to biological rates (production, respiration, consumption; derived by values reported in Tables 1 and 2). We present a plot of cumulative biomass against trophic level, and percentage cumulative production against total cumulative biomass to elucidate major, systemic patterns in biomass flows.

There are a plethora of network metrics output from the EwE software (Christensen et al., 2004; Christensen and Walters, 2004), which we present. We particularly highlight the System Omnivory Index (a measurement of how the feeding interactions are distributed among trophic levels), Finn's Cycling Index (a measure of the degree of energy re-utilization within a food web, representing the fraction of total flows of the system that is cycled), and the Lindeman pyramid (which measures the amount of biomass sequestered at each trophic level). To provide an indication of energy flow efficiency within each food web, the average trans- 
Table 3

Trophic groups described in the two models and aggregation codes (Agg.) used for the analysis. Taxa are noted as invertebrate or vertebrate; B, benthos; P, plankton; N, nekton; M, mammals; D, detritus; F, fishery; B1, commercial benthic species; N1, pelagic commercial species; N2, demersal commercial species.

\begin{tabular}{|c|c|c|c|c|c|c|c|}
\hline Taxa & Agg. & & NAS & Taxa & Agg. & & SNE \\
\hline Invert. & $\mathrm{P}$ & & Phytoplankton & Invert. & $\mathrm{P}$ & & Phytoplankton - primary producers \\
\hline Invert. & $\mathrm{P}$ & & Bacterioplankton & Invert. & $P$ & & Bacteria \\
\hline Invert. & $\mathrm{P}$ & & Microzooplankton & Invert. & $\mathrm{P}$ & & Microzooplankton \\
\hline Invert. & $\mathrm{P}$ & & Zooplankton & Invert. & $\mathrm{P}$ & & Small copepods \\
\hline Invert. & B & & Meiobenthos & Invert. & $\mathrm{P}$ & & Large Copepods \\
\hline Invert. & $\mathrm{B}$ & & Macrobenthos filter feeders & Invert. & $P$ & & Gelatinous Zooplankton \\
\hline Invert. & B & B1 & Scallops (Pectinidae) & Vert. & $\mathrm{P}$ & & Micronekton \\
\hline Invert. & B & B1 & Clams (Veneridae) & Invert. & $\mathrm{P}$ & & Mesopelagics \\
\hline Invert. & B & & Macrobenthos detritivorous & Invert. & B & & Macrobenthos - polychaetes \\
\hline Invert. & B & & Macrobenthos omnivorous & Invert. & B & & Macrobenthos - crustaceans \\
\hline Invert. & B & & Macrobenthos herbivorous & Invert. & B & & Macrobenthos - molluscs \\
\hline Invert. & B & & Macrobenthos predators & Invert. & B & & Macrobenthos - other \\
\hline Vert. & $\mathrm{N}$ & N1 & Planctivorous fish & Invert. & B & B1 & Megabenthos - filterers \\
\hline Vert. & $\mathrm{N}$ & N2 & Benthic feeders & Invert. & B & B1 & Megabenthos - other \\
\hline Vert. & $\mathrm{N}$ & N2 & Flat fish & Invert. & B & B1 & Shrimp et al. \\
\hline Vert. & $\mathrm{N}$ & N1 & Cephalopoda & Vert. & $\mathrm{P}$ & & Larval-juv fish - all \\
\hline \multirow[t]{18}{*}{ Vert. } & $\mathrm{N}$ & $\mathrm{N} 2$ & Nekton feeders & Vert. & $\mathrm{N}$ & N1 & Small Pelagics - commercial \\
\hline & $\mathrm{D}$ & & Carcasses & Vert. & $\mathrm{N}$ & N1 & Small Pelagics - other \\
\hline & $\mathrm{D}$ & & Organic matter & Vert. & $\mathrm{N}$ & N1 & Small Pelagics - squid \\
\hline & $\mathrm{D}$ & & Detritus & Vert. & $\mathrm{N}$ & N1 & Small Pelagics - anadromous \\
\hline & $\mathrm{F}$ & & Mid-water trawl & Vert. & $\mathrm{N}$ & $\mathrm{N} 2$ & Medium Pelagics - piscivores and other \\
\hline & $\mathrm{F}$ & & Hydraulic dredge & Vert. & $\mathrm{N}$ & $\mathrm{N} 2$ & Demersals - benthivores \\
\hline & $\mathrm{F}$ & & Rapido flat fish & Vert. & $\mathrm{N}$ & $\mathrm{N} 2$ & Demersals - omnivores \\
\hline & $\mathrm{F}$ & & Rapido pectinidae & Vert. & $\mathrm{N}$ & $\mathrm{N} 2$ & Demersals - piscivores \\
\hline & $\mathrm{F}$ & & Otter trawl & Vert. & $\mathrm{N}$ & & Sharks - coastal \\
\hline & & & & Vert. & $\mathrm{N}$ & & Sharks - pelagics \\
\hline & & & & Vert. & $\mathrm{N}$ & & HMS \\
\hline & & & & Vert. & M & & Pinnipeds \\
\hline & & & & Vert. & M & & Baleen whales \\
\hline & & & & Vert. & M & & Odontocetes \\
\hline & & & & Vert. & M & & Sea Birds \\
\hline & & & & & $\mathrm{D}$ & & Discard \\
\hline & & & & & $\mathrm{D}$ & & Detritus-POC \\
\hline & & & & & $\mathrm{F}$ & & Landings \\
\hline
\end{tabular}

fer efficiency across trophic levels for both ecosystems was analysed.

Moreover, we examined the informational network indices provided as output by the EwE software such as Ascendency (A). Taking into the account both the size of the ecosystem in terms of flows (total system throughput; TST) and organization (information content) has been proposed as an index to characterize the degree of development and maturity of an ecosystem (Ulanowicz, 1986). Capacity (C) represents the upper limit of A. The Relative Ascendency measure $(A / C)$ is the fraction of the potential level of organization that is actually realized (Ulanowicz, 1986). It is hypothesized that high values of this index are related to low levels of stress in the system and vice-versa. Hence disturbance activities, like eutrophication and fishing, are expected to produce a decrease in A (Wulff and Ulanowicz, 1989). The complement to A is System Overhead (O), which represents the cost to an ecosystem for circulating matter and energy (Monaco and Ulanowicz, 1997). Thus, System Overhead effectively represents the degrees of freedom a system has at its disposal to react to perturbations (Ulanowicz, 1986). For the ranking of the different compartments in term of their contribution to overall system structure and function, Ulanowicz (1997) proposed estimating the relative Ascendency of each group. That is, Ascendancy as a percentage of System Overhead is effectively a measure of resilience.

In order to assess the ecological role played by the different compartments within the two ecosystems, we use the Mixed Trophic Impact (MTI). This index, quantifying the direct and indirect interactions between functional groups, allows one to estimate the global impact of each group on the other ones (Ulanowicz and Puccia, 1990). The MTI analysis was carried out by using two different approaches, according to Libralato et al. (2004). In the first approach, the MTI $\left(m_{i, j}\right)$, weighted by the inverse of the biomass of impacted group $\left(B_{j}\right)$,

$\mathrm{aGI}_{i}=\sum_{j} m_{i, j} \frac{1}{B_{j}}$

represents the absolute effect (absolute global impact - aGI) of the variation of a unit of the impacting group and assesses the importance in terms of the functioning of a unit of biomass of each.

In the second approach the MTI, weighted by the impacting/impacted biomass ratio $\left(B_{i} / B_{j}\right)$,

$\mathrm{rGI}_{i}=\sum_{j} m_{i, j} \frac{B_{i}}{B_{j}}$

quantifies the effect on the ecosystem of a percent variation of the impacting group biomass and assesses the relative effect of a variation of the biomass of each compartment in relation to the present value (relative global impact - rGI) .

Closely related to the MTI is the keystoneness index (Libralato et al., 2006), which identifies those groups that, even if characterized by a low biomass, play an important role in structuring the ecosystem (Power et al., 1996). It is based on a plot of the overall effect $\left(\varepsilon_{i}\right)$ vs. the keystoneness $\left(K S_{i}\right)$.

The overall effect $\left(\varepsilon_{i}\right)$ is estimated from the MTI index $\left(m_{i j}\right)$ as:

$\varepsilon_{i}=\sqrt{\sum_{j=1}^{n} m_{i j}^{2}}$

The keystoneness $\left(K S_{i}\right)$ of a functional group is calculated as:

$K S_{i}=\log \left|\varepsilon_{i}\left(1-p_{i}\right)\right|$ 
where $p_{i}$ is the proportion of total system biomass made up by functional group $i$.

Finally, to assess the effects of export from the system due to fishing activities, the $L$ index, (proposed by Libralato et al., 2008) has been applied. It is based on the assumption that the export of secondary production due to fisheries reduces the energy available for upper ecosystem levels thus resulting in a loss of secondary production. The index, taking into the account ecosystem properties (primary production and transfer efficiency), and fisheries features (trophic level of catches and primary production required), allows quantifying the effects of fishing at an ecosystem level. It is calculated as:

$L=-\frac{\mathrm{PPR} \cdot \mathrm{TE}^{\mathrm{TLC}-1}}{P_{1} \cdot \ln \mathrm{TE}}$

where PPR is the primary production required to sustain the catches and is obtained by back-calculating the flows (expressed in primary production and detritus equivalents) for all pathways from the caught species down to the primary producers and detritus (Pauly and Christensen, 1995); TE is the transfer efficiency of the system; TLc is the mean trophic level of the catches; and $P_{1}$ is the primary production of the system. According to Libralato et al. (2008), it is possible to associate with each index value a probability of the ecosystem being sustainably fished and, by fixing the reference level for this probability, the index provides a basis for estimating, from an ecosystem point of view, the maximum allowable catches (ecosystem-based maximum sustainable catches - EMSC; for further details, please see Libralato et al., 2008).

\section{Results}

Both ecosystems were dominated by invertebrates in terms of biomass and production (Table 4). Ranking the major compartments in relation to their contribution to the total system biomass showed that for both ecosystems the highest rank is attained by the benthos (64\% and 48\% for NAS and SNE, respectively). Differences were seen in the secondary ranking, nekton for NAS and plankton for SNE (Table 4). These observations were reflected in the Benthos:Plankton and Nekton:Plankton ratios, which were both higher for NAS than SNE. The Benthos:Nekton ratio were quite similar in the two systems (Table 4).

In terms of production, the ranking by compartments showed a similar pattern between NAS and SNE, with production dominated by plankton followed by benthos and then nekton (Table 4). The various ratios among food web compartments also exhibited the same ranking for both ecosystems. Overall, the values for production are similar between the two systems, with the largest differ-

Table 4

Relative contribution (\%) of major compartments to total biomass and total production, and ratios between compartments. B, benthos; P, plankton; N, nekton; $\mathrm{M}$, mammals.

\begin{tabular}{llcccl}
\hline & \multicolumn{2}{l}{ Biomass } & & \multicolumn{2}{l}{ Production } \\
\cline { 2 - 3 } & NAS & SNE & & NAS & SNE \\
\hline Vertebrates & 0.21 & 0.19 & & 0.01 & 0.01 \\
Invertebrates & 0.78 & 0.81 & & 0.99 & 0.99 \\
Invert./Vert. & 3.63 & 4.22 & & 71.06 & 84.25 \\
$\mathrm{P}$ & 0.14 & 0.35 & & 0.91 & 0.97 \\
$\mathrm{~B}$ & 0.64 & 0.48 & & 0.08 & 0.03 \\
$\mathrm{~N}$ & 0.21 & 0.16 & & 0.01 & 0.002 \\
$\mathrm{M}$ & - & 0.001 & & - & $1.91 \mathrm{E}-06$ \\
$\mathrm{~B} / \mathrm{P}$ & 4.52 & 1.37 & & 0.09 & 0.03 \\
$\mathrm{~B} / \mathrm{N}$ & 2.99 & 2.94 & & 5.79 & 14.38 \\
$\mathrm{~B} / \mathrm{M}$ & - & 352.52 & & 15220.31 \\
$\mathrm{~N} / \mathrm{P}$ & 1.51 & 0.47 & 0.02 & 0.002 \\
\hline
\end{tabular}

ence being in the nekton compartment $(1.3 \%$ and $0.2 \%$, for NAS and SNE, respectively).

When cumulative biomass was plotted against trophic level, a similar pattern emerged for both ecosystems with a major accumulation of biomass between trophic levels 2 and 3 resulting in a sigmoidal curve (Fig. 3 ). This likely reflects the high benthic biomass that occurs in these systems. After trophic level 3, cumulative biomass is relatively flat, although there is a small abrupt change between TL 3-4 for SNE, due to the higher vertical diversity (in terms of species/groups) of that ecosystem. The difference in the first part of the curve is due to the higher primary producer biomass recorded in the SNE system.

Cumulative biomass vs. cumulative production showed a "hockey stick" configuration, suggesting a steep rise in biomass and production followed by a slow levelling out at the highest values of biomass and production (Fig. 4). The main difference being that the SNE curve exhibited a much more gradual rise than in the NAS. This more gradual rise suggests either a less productive system per unit biomass or perhaps higher vertical diversity.

Network flows and information indices are reported in Table 5. As expected, almost all values referred to the structure and dimension of the flows were 3-4 times higher in the SNE than in the NAS ecosystem (Table 5). In relative terms, however, the two systems are very similar, with Total Consumption dominating total system throughput (43\% and $47 \%$, for NAS and SNE, respectively) and the same Total primary production/total respiration ratio (1.23) for both ecosystems (with the reference value about 1.00). Addition-

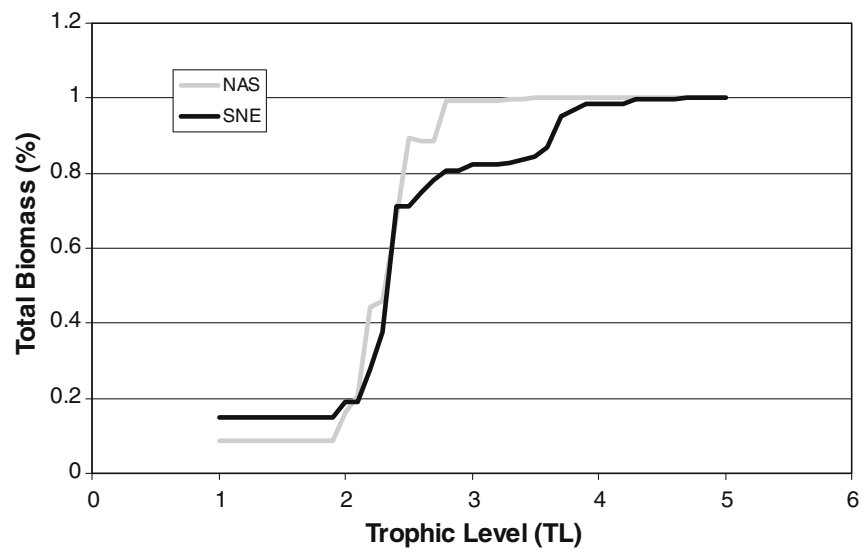

Fig. 3. Cumulative biomass plotted against trophic level for the two ecosystems.

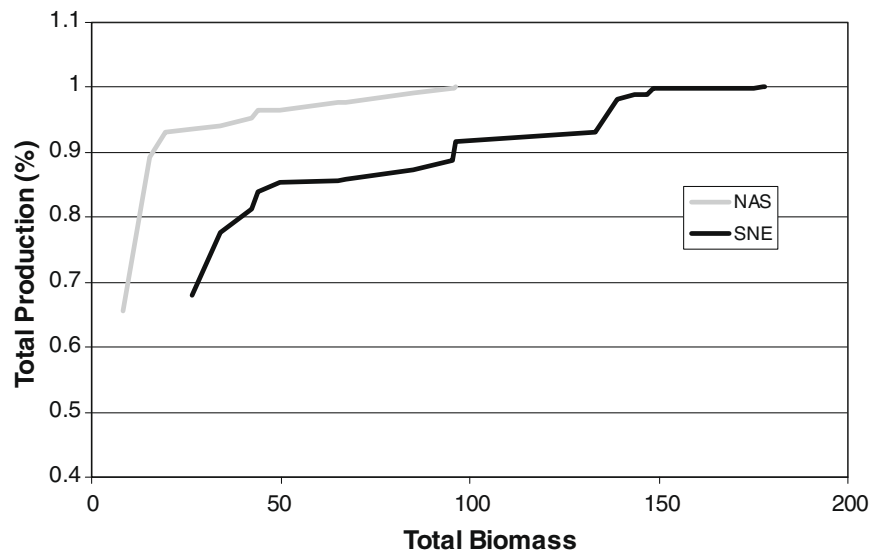

Fig. 4. Cumulative production plotted against cumulative biomass for the two ecosystems. 
Table 5

Summary statistics after mass balancing and network flow indices.

\begin{tabular}{|c|c|c|c|}
\hline \multicolumn{2}{|l|}{ Parameter } & \multirow{2}{*}{$\begin{array}{l}\text { NAS } \\
2128.89\end{array}$} & \multirow{2}{*}{$\begin{array}{l}\text { SNE } \\
8528.93\end{array}$} \\
\hline Sum of all consumption & $\mathrm{t} \mathrm{km}^{-2} \mathrm{yr}^{-1}$ & & \\
\hline Sum of all exports & $\mathrm{t} \mathrm{km}^{-2} \mathrm{yr}^{-1}$ & 242.84 & 812.82 \\
\hline Sum of all respiratory flows & $\mathrm{t} \mathrm{km}^{-2} \mathrm{yr}^{-1}$ & 1035.69 & 4038.61 \\
\hline Sum of all flows into detritus & $\mathrm{t} \mathrm{km}^{-2} \mathrm{yr}^{-1}$ & 1518.34 & 4782.62 \\
\hline Total system throughput & $\mathrm{t} \mathrm{km}^{-2} \mathrm{yr}^{-1}$ & 4926 & 18163 \\
\hline Sum of all production & $\mathrm{t} \mathrm{km}^{-2} \mathrm{yr}^{-1}$ & 1947 & 7132 \\
\hline Gross efficiency (catch/net p.p.) & & 0.0019 & 0.0008 \\
\hline Calculated total net primary production & $\mathrm{t} \mathrm{km}^{-2} \mathrm{yr}^{-1}$ & 1277.92 & 4850.90 \\
\hline Total primary production/total respiration & & 1.234 & 1.201 \\
\hline Net system production & $\mathrm{t} \mathrm{km}^{-2} \mathrm{yr}^{-1}$ & 242.22 & 812.29 \\
\hline Total primary production/total biomass & & 13.30 & 27.24 \\
\hline Total biomass/total throughput & & 0.02 & 0.01 \\
\hline Total biomass (excluding detritus) & $\mathrm{t} \mathrm{km}^{-2}$ & 96.09 & 178.10 \\
\hline Connectance Index & & 0.374 & 0.334 \\
\hline System Omnivory Index & & 0.201 & 0.303 \\
\hline Throughput cycled (excluding detritus) & $\mathrm{t} \mathrm{km}^{-2} \mathrm{yr}^{-1}$ & 23.69 & 498.72 \\
\hline Predatory cycling index & $\%$ of throughput $\mathrm{w} / \mathrm{o}$ detritus & 1.04 & 5.80 \\
\hline Throughput cycled (including detritus) & $\mathrm{t} \mathrm{km}^{-2} \mathrm{yr}^{-1}$ & 395.03 & 2577.27 \\
\hline Finn's cycling index & $\%$ of total throughput & 8.02 & 14.19 \\
\hline Finn's mean path length & & 3.852 & 3.744 \\
\hline Finn's straight-through path length & Without detritus & 2.167 & 1.984 \\
\hline Finn's straight-through path length & With detritus & 3.543 & 3.212 \\
\hline Ascendancy/capacity (A/C) & $(\%)$ & 32.5 & 18.9 \\
\hline Overhead/capacity $(\mathrm{O} / \mathrm{C})$ & $(\%)$ & 67.5 & 87.1 \\
\hline
\end{tabular}

ally, the structure of the food web was quite similar for the two systems, as highlighted by the Connectance Index (Table 5). In terms of complexity, both systems showed low values of the System Omnivory Index relative to other published models (e.g. Monaco and Ulanowicz, 1997). This suggests that these two food webs exhibited a relatively linear topology.

The SNE ecosystem showed a higher cycling capacity than NAS, as suggested by the Finn's Cycling Index (FCI). However, in both ecosystems, the high FCI values indicate that these food webs have a large amount of cycling through detritus, revealing a major dependency on detritus-related processes (Table 5). This is especially true for the NAS ecosystem.

Table 6 summarizes the flows organized by integer trophic levels in the Lindeman pyramid. In both ecosystems, the TL 1 and 2 accounted for more than $90 \%$ of the flows, with the values recorded in NAS slightly higher than those of SNE. The pattern reverses for the following TLs (3-4), with SNE values higher at those upper trophic levels.

The average transfer efficiency (TE) values were lower for NAS than SNE (8.4 and 15.5, respectively). These values confirm that, on average, food webs more strongly associated with detritus tend to be less efficient than those more directly reliant upon primary producers. The pattern obtained by plotting the TE for each trophic level (TL) elucidates the decline in efficiency as TL increases, with a minor increase at TLs 7 and 8 (Fig. 5).

Upon examining the information indices, both systems showed relatively low values of Ascendency/Capacity $(\mathrm{A} / \mathrm{C})$ and conversely high values of Overhead/Capacity $(\mathrm{O} / \mathrm{C})$; that is a high maturity and

\section{Table 6}

Lindeman pyramid of flows in each ecosystem; values are expressed as percentage of total system throughput (TST). Integers represent trophic levels.

\begin{tabular}{lll}
\hline TL & NAS & SNE \\
\hline 6 & 0.001 & 0.014 \\
5 & 0.018 & 0.129 \\
4 & 0.4 & 1.0 \\
3 & 4 & 7 \\
2 & 38 & 37 \\
1 & 57 & 55 \\
\hline
\end{tabular}

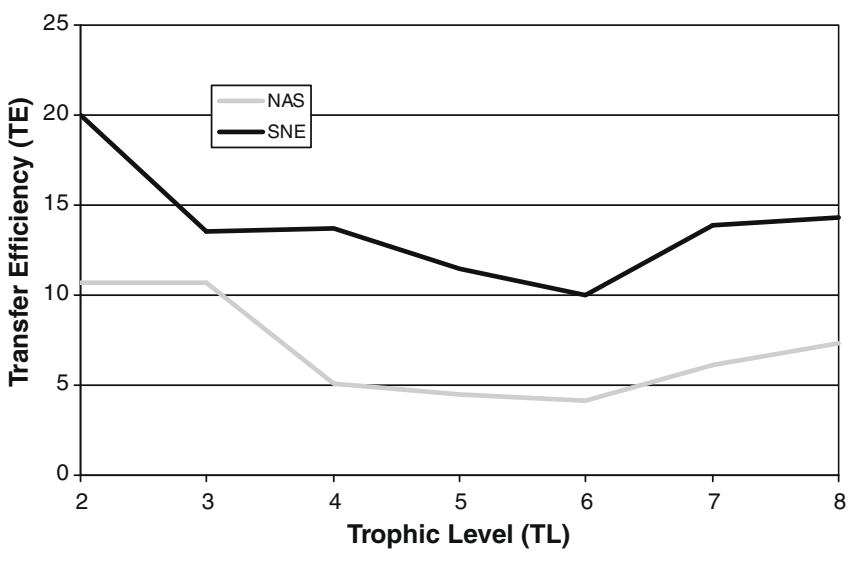

Fig. 5. Transfer efficiency plotted against trophic level for the two ecosystems.

a high potential resistance to external perturbation (Table 5). The contribution of each group to Ascendency showed the importance of detritus in the NAS and detritus and plankton in SNE (Table 7). Benthos and nekton exhibited the same ranking values in the two systems, even with different contributions to Ascendancy.

The MTI values, evaluated as relative global impact (rGI), confirm the importance of invertebrates for both ecosystems (Fig. 6).

Table 7

Relative contribution to Ascendency by the major compartments in the two ecosystems. Vert., vertebrates; invert., invertebrates; $\mathrm{B}$, benthos; $\mathrm{P}$, plankton; $\mathrm{N}$, nekton; M, mammals; D, detritus.

\begin{tabular}{lll}
\hline & NAS & SNE \\
\hline Vert.\% & 0.03 & 0.05 \\
Invert.\% & 0.51 & 0.59 \\
P\% & 0.36 & 0.55 \\
B\% & 0.15 & 0.08 \\
N\% & 0.03 & 0.005 \\
M\% & - & 0.0002 \\
D\% & 0.46 & 0.37 \\
\hline
\end{tabular}



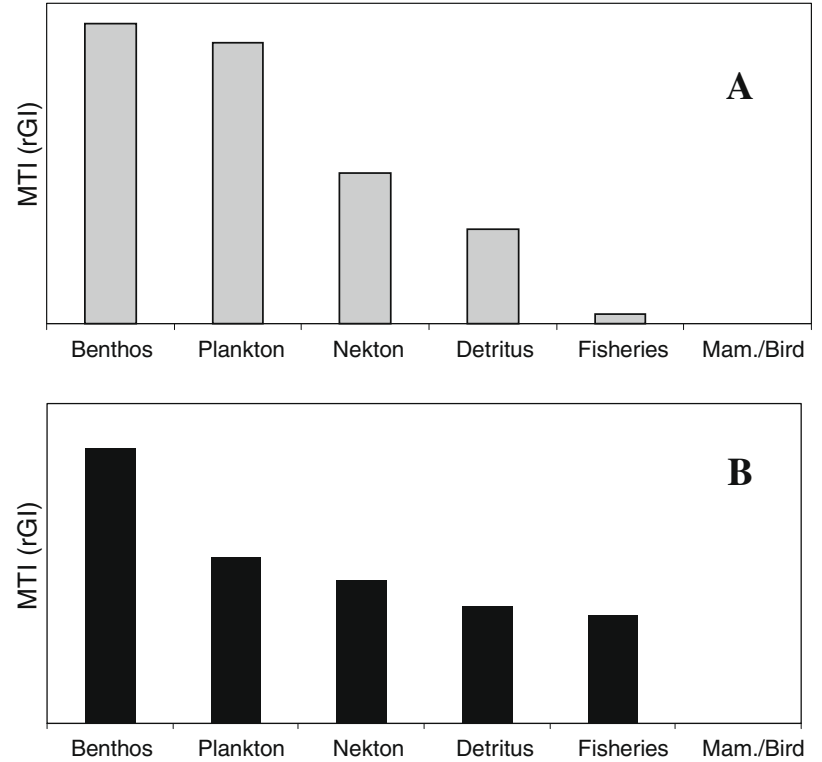

Fig. 6. Mixed Trophic Impact, overall (MTI rGI) analysis; (A) NAS, (B) SNE.

The ranking for the compartments reflects the biomass patterns, highlighting the importance of the benthos. Regarding the exploited groups, the same pattern is observed in NAS and SNE, with the pelagic fish playing the most important role (Table 8 and Fig. 4). The analysis of the MTI, evaluated as absolute global impact (aGI) showed the importance of vertebrates in determining the functioning of both systems, with particular emphasis to the top-down effects due to the nekton group (Table 8 and Fig. 7). The ranking for the compartments also underpins the important ecological role played by both fishing activities and plankton, respectively, for NAS and SNE (Table 8 and Fig. 7). Finally, the presence of top-down effects is implied by the higher values for the fishery groups (Table 8 and Fig. 7).

The keystoneness index analysis was performed without any aggregation and the original nodes can be recognized. The top groups were phytoplankton and two macrobenthic groups (detri-
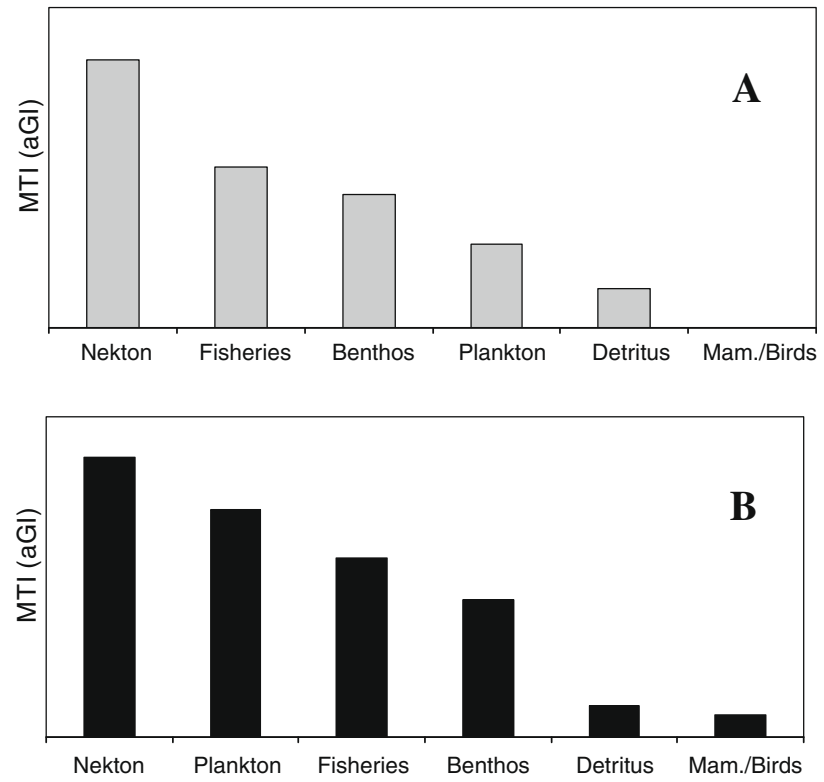

Fig. 7. Mixed Trophic Impact, biomass effect (MTI aGI) analysis; (A) NAS, (B) SNE.
Table 8

Mixed Trophic Impact (biomass ratio) analysis. B, benthos; P, plankton; N, nekton; $\mathrm{M}$, mammals; D, detritus; F, fishery; B1, commercial benthic species; N1, pelagic commercial species; N2, demersal commercial species.

\begin{tabular}{lccccc}
\hline & \multicolumn{2}{l}{ MTI (overall effect) $\mathrm{rGI}$} & & \multicolumn{2}{c}{ MTI (unit of biomass effect) aGI } \\
\cline { 2 - 3 } & NAS & SNE & & NAS & SNE \\
\hline Vert. & 306.72 & 1459.16 & & 58.46 & 476.71 \\
Invert. & 430.32 & 4035.86 & & 47.43 & 461.92 \\
P & 102.78 & 1559.21 & & 18.26 & 320.18 \\
B & 327.54 & 2588.33 & & 29.17 & 192.98 \\
N & 306.71 & 1345.67 & & 58.46 & 393.38 \\
M & - & 1.81 & & - & 32.08 \\
D & 163.99 & 1102.67 & & 8.44 & 44.44 \\
F & 11.07 & 1014.63 & & 35.18 & 252.40 \\
B1 & 3.98 & 220.48 & & 5.18 & 64.97 \\
N1 & 303.10 & 1233.63 & & 21.05 & 48.25 \\
N2 & 3.62 & 108.65 & 37.41 & \\
\hline
\end{tabular}

tus feeders and omnivores) for the NAS ecosystem, whereas for the SNE the top groups were large copepods, gelatinous zooplankton and phytoplankton (Fig. 8). This again confirms the relative importance of planktonic groups in SNE when compared to NAS.

Relative to the exploitation of natural resources by fishing activities (Table 9), the higher productivity of the SNE ecosystem is re-
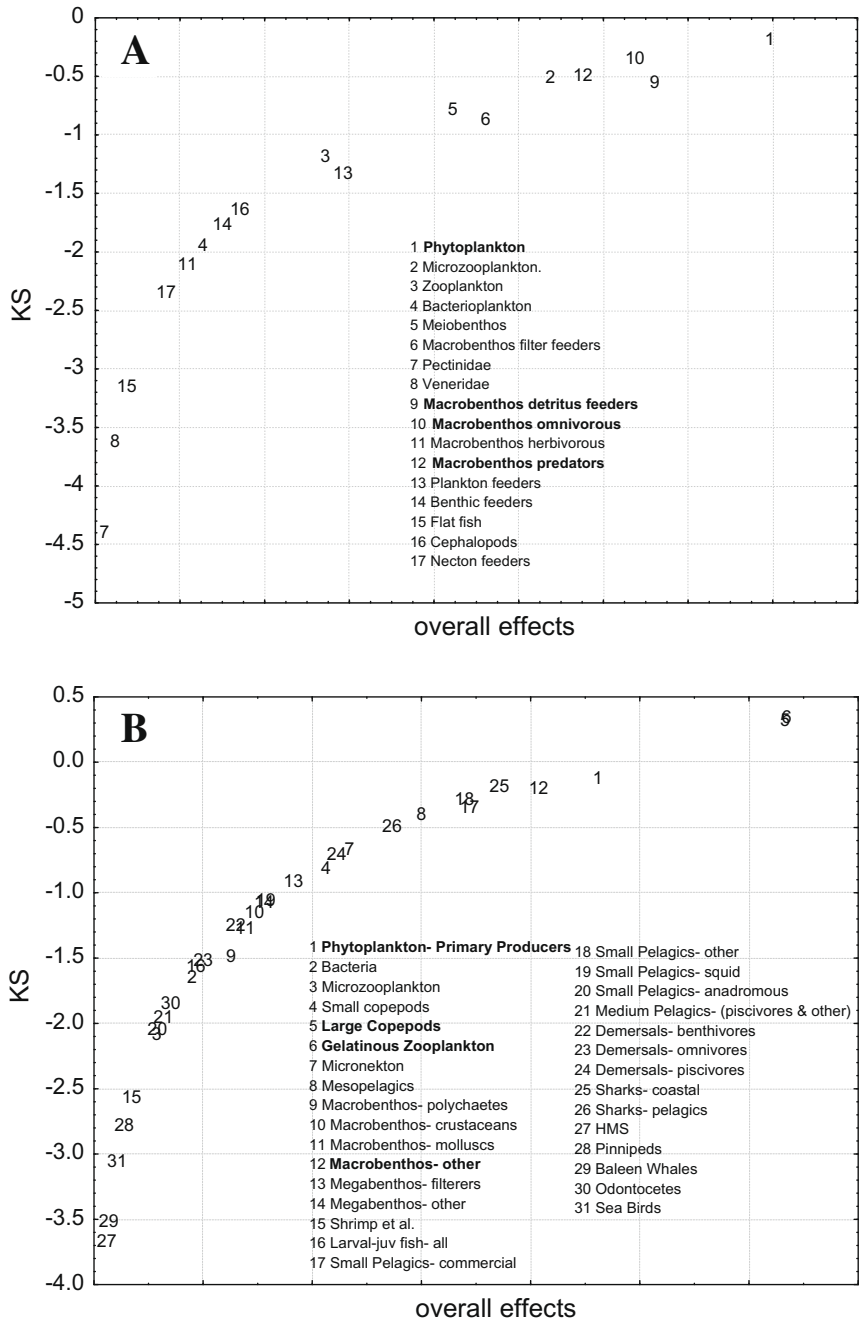

Fig. 8. Keystoneness index $\left(\mathrm{KS}_{i}\right)$ and overall effect $\left(\varepsilon_{i}\right)$ of each functional group; (A) NAS, (B) SNE. Keystone groups are those with higher $\varepsilon_{i}$ and higher $\mathrm{KS}_{i}$. 
Table 9

Comparison between the two ecosystems in terms of species targeted and discarded by fishing activities.

\begin{tabular}{llll}
\hline & & NAS & SNE \\
\hline Target species $\left(\mathrm{t} \mathrm{km}^{-2} \mathrm{yr}^{-1}\right)$ & Zooplankton & - & - \\
& Macrobenthos & 1.177 & 1.851 \\
& Pelagic fish & 0.444 & 0.873 \\
& Benthic fish & 0.140 & 0.317 \\
& Sharks & - & 0.008 \\
& Marine mammals & - & 0.001 \\
& Sea birds & & - \\
& Total catch & 1.761 & 3.050 \\
Discarded species $\left(\mathrm{t} \mathrm{km}^{-2} \mathrm{yr}^{-1}\right)$ & Zooplankton & - & 0.009 \\
& Macrobenthos & 0.586 & 0.582 \\
& Pelagic fish & 0.017 & 0.255 \\
& Benthic fish & 0.007 & 0.122 \\
& Sharks & - & 0.004 \\
& Marine mammals & - & $3.0 \mathrm{E}-08$ \\
& Sea birds & & $6.3 \mathrm{E}-05$ \\
& Total catch & 0.610 & 0.972 \\
\hline
\end{tabular}

flected in the higher biomass of total catches $\left(4.02 \mathrm{t} \mathrm{km}^{-2} \mathrm{yr}^{-1}\right.$ and $2.37 \mathrm{t} \mathrm{km}^{-2} \mathrm{yr}^{-1}$, respectively) for SNE compared to NAS. Differences were also seen in the mean trophic level of the catch $(2.57$ for NAS and 2.90 for SNE). However, the two ecosystems showed similarities, particularly in the macrobenthic compartment, with both ecosystems having comparable values for targeted and discarded quantities of macrobenthos (Table 9). The fishing activities result in an exploitation of $46 \%$ of the production of macrobenthic commercial groups in the NAS and only 3\% in the SNE (Table 10). The values were more comparable between the two systems for the exploited groups in the Nekton compartment (Table 10).

Despite differences in terms of production, flow structures and transfer efficiency, both systems showed almost the same value of the L index (0.108 and 0.116, respectively, for NAS and SNE; Table 11). By using the classification parameters proposed by Libralato et al. (2008), these values result in a very high probability $(>80 \%)$ of having been subjected to an unsustainable fishing regime (Table 11). Extended further, a key interpretation of these results would be that in order to increase the probability of sustainably fishing

\section{Table 10}

Ratios between total catch and production or consumption for the major targeted groups. B1, commercial benthic species; N1, pelagic commercial species; N2, demersal commercial species.

\begin{tabular}{|c|c|c|c|c|}
\hline & \multicolumn{2}{|c|}{ Total catch/P } & \multicolumn{2}{|c|}{ Total catch/Q } \\
\hline & NAS & SNE & NAS & SNE \\
\hline B1 & 0.46 & 0.03 & 0.09 & 0.01 \\
\hline N1 & 0.02 & 0.06 & 0.01 & 0.01 \\
\hline N2 & 0.11 & 0.14 & 0.03 & 0.07 \\
\hline
\end{tabular}

these food webs to $75 \%$, a reduction of about $80 \%$ of present total catches would be required for both ecosystems (Table 12).

\section{Discussion}

\subsection{Contrasts between NAS and SNE}

In general terms, results from the structure and trophic flow analysis of the two ecosystems studied here demonstrated congruence with previous studies carried out in both ecosystems. The South New England (SNE) ecosystem is confirmed as one of the most productive marine areas on the planet (Bax, 1991; Cohen et al., 1982; Grosslein et al., 1980; Sissenwine et al., 1984); whereas, the Northern Adriatic Sea (NAS) system is confirmed as one of the most productive areas within the Mediterranean basin (Bosc et al., 2004; Turley, 1999). The semi-enclosed (NAS) vs. open system (SNE) comparison results in a large absolute difference between the structure and flows of the two ecosystems, with the NAS model 3-4 times less than the SNE model results.

Notwithstanding the differences in the ecosystems and models thereof, some similar features were noted. Both ecosystems are dominated by benthic biomass and plankton production. In terms of structure (e.g. biomass composition), the importance of the benthic compartment was also confirmed by the 'accumulation' of biomass recorded between TL 2 and 3, which results in a sort of inverted trophic pyramid. This pattern would be in accordance with the hypothesis suggested by Fath and Killian (2007) about the typical marine ecosystem trophic structure which is different from the classic (and terrestrial-based) Eltonian pyramid.

The transfer efficiency for the SNE food web is higher than the upper end of average values (8-15\%) reported by other authors (e.g. Christensen and Pauly, 1993; Wolff, 1994; Wolff et al., 1996), but comparable with those reported for other North-western Atlantic ecosystems (Link et al., 2006). On the contrary, NAS TE values are very close to those reported by Coll et al. (2007) for the North Central Adriatic basin and are in the lower part of the range. This highlights a significant difference in the efficiency between the two ecosystems. The higher efficiency of SNE is also confirmed by several of the other cycling indices. This difference could be related to the higher complexity of the SNE ecosystem. Further, in the SNE ecosystem there is a more even biomass distribution among different compartments, whereas the NAS is dominated by benthos. With almost $65 \%$ of the total biomass in the benthos, the biomass ratios are skewed towards the benthos in the NAS compared to SNE. All these properties can directly affect the resistance/resilience of the systems. According to theoretical and real system analysis, both energy cycling and transfer efficiency relate in a nonlinear but notable way to other system properties such as stability (de Ruiter et al., 1995; McCann et al., 1998; Neutel et al., 2007). This would suggest the importance of taking into

Table 11

Estimated probabilities of the ecosystem being sustainably fished ( $p_{\text {sust }}$ ) and ecosystem-based maximum sustainable catches (EMSC) for different values of $p_{\text {sust }}$ ( $75 \%$ and $95 \%$ ). TE, transfer efficiency; PP, primary production; TLc, trophic level of catch; PPR, primary production required.

\begin{tabular}{|c|c|c|c|c|c|c|c|}
\hline & TE (\%) & $\mathrm{PP}\left(\mathrm{gC} \mathrm{m}^{-2} \mathrm{yr}^{-1}\right)$ & TLC & Catch and discards $\left(\mathrm{t} \mathrm{km}^{-2} \mathrm{yr}^{-1}\right)$ & PPR (\%) & $L$ index & $p_{\text {sust }}(\%)$ \\
\hline NAS & 8.4 & 142 & 2.57 & 2.372 & 13.0 & 0.1081 & 18.9 \\
\hline SNE & 15.5 & 539 & 2.90 & 4.026 & 7.6 & 0.1165 & 18.9 \\
\hline
\end{tabular}

Table 12

Ecosystem-based maximum sustainable catches (EMSC) for different values of $p_{\text {sust }}(50 \%, 75 \%$ and $95 \%$ ).

\begin{tabular}{llllll}
\hline & EMSC $_{50}\left(\mathrm{t} \mathrm{km}^{-2} \mathrm{yr}^{-1}\right)$ & Change $_{50}(\%)$ & $\mathrm{EMSC}_{75}\left(\mathrm{t} \mathrm{km}^{-2} \mathrm{yr}^{-1}\right)$ & $\mathrm{Change}_{75}(\%)$ & $\mathrm{EMSC}_{95}\left(\mathrm{t} \mathrm{km}{ }^{-2} \mathrm{yr}^{-1}\right)$ \\
\hline NAS & 1.095 & -57 & 0.450 & -82 & 0.193 \\
SNE & 1.725 & -41 & 0.709 & -76 & -92 \\
\hline
\end{tabular}


the account the vertical biodiversity (multi-trophic analysis) of an ecosystem (Raffaelli, 2006).

Results indicate that for both ecosystems there is the presence of an important coupling between the pelagic and demersal compartments - mainly due to the link among detritus, benthic and pelagic invertebrates. This is likely explained by the shallow waters and the oceanographic features of both these areas which create specific ecological conditions related to water exchanges and recirculation of nutrients. Moreover, the link between detritus and benthic organisms could be partially enhanced by fishing activity, which generates important amounts of discards (0.610 and $0.972 \mathrm{t} \mathrm{km}^{-2}$ for NAS and SNE, respectively) and increases biomass and energy flows towards detritus. These detrital enhancement activities also directly influence trophic webs, shortening path length, by-passing predation cycles and increasing microbial loops (Azam et al., 1983; Jones, 1992; Dayton et al., 1995; Kaiser and de Groot, 2000).

In terms of fishing activities, the NAS and SNE show interesting similarities. The gross efficiency of the fishery from both ecosystems was high when compared to the average of 0.0002 reported from global data (Christensen et al., 2004). The mean trophic level of the catch (TLC) recorded for both was lower than values obtained for other systems, such as the North and Central Adriatic basin $(\mathrm{TL}=3.07$, Coll et al., 2007) and the Mediterranean Sea $(\mathrm{TL}=3.0$, Pauly et al., 1998), reflecting the composition of catches and particularly the important contribution of benthic invertebrates $(67 \%$ and 39\%, respectively, for NAS and SNE) and small pelagic fish (25\% and 29\%, respectively, for NAS and SNE). The incidence of discarding of total catch was about $25 \%$ (26\% for NAS and $24 \%$ for SNE), with this value probably indicative of low sustainability of the fishing activity (Kelleher, 2005).

\subsection{Utility of novel metrics}

Ascendency and capacity represent two holistic measures derived from the analysis of networks of trophic exchanges. Again Ascendency is defined as an index that characterizes the degree of system development and maturity, incorporating both growth and development (Ulanowicz, 1986). Capacity is associated with the scope of the system for further development and represents the mathematical upper bound on Ascendancy (Ulanowicz and Norden, 1990), with System Overhead being the difference between the two. Results suggest (Ortiz and Wolff, 2002) that both ecosystems are immature (low Ascendency) and have a high resistance to external perturbations (i.e. high System Overhead). The differences in terms of System Overhead between NAS and SNE (a lower value for NAS) would suggest a higher risk for the NAS ecosystem in relation to external pressures.

The preceding cybernetic considerations are confirmed by the cycling indices, such as Finn's Cycling Index. Odum (1969) notes that the FCI is expected to increase with maturation of the ecosystem. It has been observed, however, that disturbed systems often exhibit greater degrees of recycling. The explanation would be that such an increase in cycling in disturbed systems is a homeostatic response that maintains in circulation resources which previously were stored as biomass in higher trophic level organisms before the perturbation (Ulanowicz and Wulff, 1991; Patrìcio et al., 2006). The ranking of different compartments according to their contribution to total Ascendency highlights an important difference between the two systems. In the context of the importance of the lower trophic level production, the results suggest that NAS is more dependent on detritus whereas SNE is more dependent upon primary production. Environmental management deals with dynamic systems which change through time. In this context, concepts of stability and maturity (sensu Odum, 1969) seem to play a crucial role for the possible success of management policies.
Ecosystem stability is an important emergent property determining the sustainability of all ecological functions, goods and services conveyed to society. Ecosystem stability can be assessed through two traits. The resistance of the ecosystem to external forcing and disturbance and the resilience of the ecosystem, referring to its capacity to return to the original state after this has been altered by significant disturbance (Holling, 1996). Thus, ecosystem stability is an essential feature to consider in the framework of renewable resources management, since ecosystems that have low resilience will be particularly vulnerable to external forcing factors. When change occurs resilience allows (via the various ecosystem components) for renewal and reorganization (Gunderson and Holling, 2002; Berkes et al., 2002). Vulnerability is the opposite of resilience: when an ecological system loses resilience it becomes vulnerable to change that previously could be absorbed (Kasperson and Kasperson, 2001). Anthropogenic pressures (such as fishing activities or eutrophication) that change the ecosystem structure can also affect ecosystem functioning, thereby making the system more vulnerable to other disturbances (both natural and humaninduced), while at the same time reducing resilience, and so on. Conversely, once the system has been shifted to another stable state, it is possible that the new state, even if less desirable, is more stable in terms of resistance than the previous one (Scheffer et al., 2001).

The importance of resistance/resilience in a management context is complicated by the absence of appropriate metrics to quantify it. Indeed, which metrics reflect these ecosystem features, especially in real systems, still remain an unsolved issue. According to Cury et al. (2005), a modeling approach could be used to explore dynamic stability (see also Vasconcellos et al., 1997; Pérez-España and Arreguin-Sánchez, 1999), but the specific relevant metrics remain to be determined. Thus, our proposal is that some of the novel metrics here should at least be considered to enhance ecosystem-based management.

In the context of analysis of ecosystem function, the keystoneness and MTI index quantify the trophic interactions among the different functional groups. These indices define the relative importance of the ecological role played by each group. Our results describe a similar pattern for both ecosystems, despite some small distinctions, emphasizing the prominence of benthic and planktonic organisms. In terms of 'keystone species/groups' the importance of planktonic invertebrates for the SNE system and benthic groups for the NAS system are highlighted, confirming the differences previously described. The keystoneness index application confirms the hypothesis that keystone species/groups do not always exert a high impact by means of top-down effects (Libralato et al., 2006), a feature initially suggested to be a defining characteristic of keystone species (Paine, 1969).

Furthermore, the MTI analysis demonstrates that both ecosystems are controlled by the benthic compartment in terms of overall effects (MTI rGI), with a general pattern reflecting the importance of each compartment in terms of biomass. Removing the biomass effect raises the importance of the ecological role played by the nekton, with a clear top-down effect. In this context, the high rank achieved by the fisheries is noteworthy, emphasizing the important ecological role of exploitation. In sum, these observations could have important consequences to ecosystem function in relation to the disturbances associated with exploitation. This would be similar to the hypothesis suggested by Frank et al. (2006, 2007) of a top-down control within mid-latitude marine ecosystems that is strongly modulated by bottom-up productivity. According to Strong (1992), top-down control would not represent the norm for marine ecosystems, but instead represent a form of biological instability, particularly if in response to heavy exploitation by fisheries. The existence of top-down controls in exploited ecosystems does not necessarily lead to trophic cascades, but can 
be viewed as an initial step towards alternate states (Frank et al., 2007). All these points underpin the importance of analyzing the state of ecological systems to be managed in relation to the main features of stability via these novel metrics.

The $L$ index highlights the presence of an ecosystem overfishing proxy (sensu Murawski, 2000; Link, 2005) in both ecosystems. As suggested by the high values of the fishery efficiency index, the fishing in these ecosystems harvests at low trophic levels. This results in a low mTL of catches and high PPR, features usually linked to unsustainable fishing strategies (Pauly et al., 2002). As demonstrated by Libralato et al. (2008), high PPR values are only compatible with fisheries harvesting the higher part of the food web. The $L$ index results obtained for NAS and SNE concur with similar values reported globally for other ecosystems (Libralato et al., 2008). To increase the probability of fishing in a sustainable manner to $50 \%$, it would be necessary to reduce the present level of exploitation by more than $40 \%$. In the implementation of ecosystem-based fishery management, the values reported here can serve as a first approximation of potential systemic reference levels.

We assert that to fully capture patterns and spatial/temporal trends when dealing with dynamic systems, it is necessary to have multiple perspectives. In this context and relative to the discussion about implications of stability for ecosystem management, multiple metrics are more insightful than just a few limited ones.

\subsection{Value of comparative studies}

The implementation of an EBM approach can benefit from the developing body of knowledge on ecosystem functioning and ecosystem responses to perturbations such as fishing. In this context, there is a need to move towards larger spatial and temporal scales, towards greater trophic complexity and towards connections to biodiversity policy being developed at the ecosystem level (Jorgensen, 1992; Link, 2002). Small-scale experiments will remain useful for identifying mechanisms and testing specific hypotheses, but macro-ecological and ecosystem ecology approaches have a stronger potential for successfully addressing issues of scale, complexity and socio-economic concerns. To reach these goals, models and comparisons between different ecosystems can serve as a useful tool (Raffaelli, 2006).

The comparisons presented here highlight that quite different ecosystems, both in terms of real structure (semi-enclosed vs. open basin) and model representations (different aggregations adopted) show similar features. Being subjected to high levels of fishing pressure resulted in similar responses in these ecosystems, such as: a simplified trophic web topology (relatively linear); ecosystem control shifted towards high trophic levels and benthic compartments; and the keystone roles played by nekton compartment. Thus, it seems feasible to recognize signals of ecosystem effects induced by exploitation activities. It also seems apparent that there are fundamental ecosystem processes occurring in both ecosystems that may lead to a better general understanding of ecosystem responses to over-exploitation (sensu Murawski, 2000; Link, 2005).

It is virtually impossible to conduct experiments on full ecosystems, particularly at the scales associated with large marine ecosystems. Therefore, comparative studies are highly valuable to elucidate those common, fundamental, and unique processes and patterns in these marine ecosystems. In many respects, comparisons of comparable ecosystems serve as "replicate" responses in a pseudo-experimental sense. The work presented here particularly highlights both common and unique features of SNE and NAS ecosystems. Comparative analyses such as this will continue to provide an opportunity for taking a broader ecosystem perspective and permit the ability to draw generalizations important to the successful implementation of EBM.

\section{Acknowledgments}

We thank the CNR (Consiglio Nazionale delle Ricerche - Short term mobility program) for providing a travel fellowship to F.P. which initiated this collaboration. We thank S. Gaichas and anonymous reviewers of prior versions of the article which improved its quality and content.

\section{Appendix A}

The Northern Adriatic Sea (NAS) model is composed of 20 nodes, ranging from phytoplankton and bacteria to piscivorous fish, plus three groups for non-living organic matter and detritus. This formulation represents the ecosystem during 1997-2000. The complete list of nodes is reported in Table A1. Due primarily to the lack of data for the reference years, marine mammals and birds were not represented in the model. Units of the model are expressed in $\mathrm{t} \mathrm{km}^{-2} \mathrm{yr}^{-1}$ wet weight organic matter for flows and $\mathrm{t} \mathrm{km}^{-2}$ for biomasses.

For the lower trophic levels, we established phytoplankton, bacterioplankton, microzooplankton and zooplankton nodes for the model. These nodes were kept as aggregate groups due to the generally limited information available for such taxa. Biomass estimates as well as vital rate parameters $(\mathrm{P} / \mathrm{B})$ were taken from multiple literature sources from studies conducted in the region (Table A2). There were no consumption $(\mathrm{Q} / \mathrm{B})$ or respiration estimates, and thus we allowed the model to fit those values for these nodes. Estimates of feeding by and on these nodes were also obtained from literature values (Tables A3 and A4).

Because the NAS is relatively shallow with a well-developed shelf, the benthic component of the food web was particularly emphasized. For the benthic organisms, there were eight nodes

\section{Table A1}

Species composition of the NAS model groups.

Group

Phytoplankton

Bacterioplankton

Microzooplankton

Zooplankton

Meiobenthos

Macrobenthos

herbivorous

Macrobenthos

omnivorous

Macrobenthos

detritivorous

Macrobenthos filter Bivalvia, Crustacea, Polychaeta,

feeders

Scallops (Pectinidae) Pecten jacobeus, Aequipecten opercularis

Clams (Veneridae) Chamelea gallina, Callista chione

Macrobenthos Asteroidea, Decapoda, Gastropoda, Polychaeta, Stomatopoda

predator

Planktivorous fish Engraulis encrasicholus, Sardina pilchardus, Scomber scombrus, Sprattus sprattus

Cephalopods $\quad$ Alloteuthis media, Eledone moscata, Loligo vulgaris, Octopus

vulgaris, Sepia elegans, S. officinalis

Benthic feeders $\quad$ Gobius niger, Lepidotrigla cavillone, Mullus barbatus, M. surmuletus, Pagellus erythrinus, Sparus aurata, Trachurus trachurus, T. mediterraneus, Trigla lyra, T. lucerna, Trigloporus lastoviza, Trisopterus minutus capelanus, Umbrina cirrosa

Flatfish Arnoglossus laterna, Buglossidium luteum, Citharus linguatula Microchirus variegatus, Platichthys flesus, Psetta maxima, Scophthalmus rhombus, Solea vulgaris

Nekton feeders Dicentrarchus labrax, Lophius budegassa, L. piscatorius, Merluccius merluccius, Mustelus mustelus, M. asterias, Squalus acanthias

Carcasses

Organic matter

Detritus 
Table A2

Input data and references by functional group for the Northern Adriatic Sea model.

\begin{tabular}{|c|c|c|c|c|c|c|}
\hline Group & $\mathrm{B}\left(\mathrm{t} \mathrm{km^{-2 } )}\right.$ & & $\mathrm{P} / \mathrm{B}\left(\mathrm{yr}^{-1}\right)$ & & $\mathrm{Q} / \mathrm{B}\left(\mathrm{yr}^{-1}\right)$ & \\
\hline Phytoplankton & 8.4 & A, B, C & 152.133 & $\mathrm{~B}, \mathrm{C}$ & & \\
\hline Bacterioplankton & 2.138 & A, B, C & 34.348 & $\mathrm{D}$ & & \\
\hline Microzooplankton & 1.758 & E & 219 & $\mathrm{~F}$ & & \\
\hline Zooplankton & 1.456 & A, B, C & 18.25 & $\mathrm{~B}, \mathrm{C}$ & & \\
\hline Meiobenthos & 5.311 & G, H & & & 68.52 & $\mathrm{~L}$ \\
\hline Macrobenthos herbivorous & 2.086 & $\mathrm{G}, \mathrm{H}, \mathrm{M}$ & 1.746 & $\mathrm{I}, \mathrm{J}, \mathrm{K}$ & & \\
\hline Macrobenthos omnivorous & 3.118 & $\mathrm{G}, \mathrm{H}, \mathrm{M}$ & 2.313 & I, J, K & & \\
\hline Macrobenthos detritivorous & 22.834 & $\mathrm{G}, \mathrm{H}, \mathrm{M}$ & 1.692 & I, J, K & & \\
\hline Macrobenthos filter feeders & 19.642 & $\mathrm{G}, \mathrm{H}, \mathrm{M}$ & 1.07 & I, J, K & & \\
\hline Scallops (Pectinidae) & 0.756 & $\mathrm{G}, \mathrm{H}, \mathrm{M}$ & 0.7 & $\mathrm{~N}$ & & \\
\hline Clams (Veneridae) & 1.397 & $\mathrm{O}, \mathrm{P}$ & 1.41 & I, J, K & & \\
\hline Macrobenthos predator & 7.033 & $\mathrm{G}, \mathrm{H}, \mathrm{M}$ & 1.5 & $\mathrm{I}, \mathrm{J}, \mathrm{K}$ & & \\
\hline Planktivorous fish & 19.996 & Q, R & 1.295 & $\mathrm{~S}, \mathrm{~T}$ & 3.882 & $\mathrm{~S}$ \\
\hline Cephalopods & 0.35 & $\mathrm{U}$ & 1.45 & $\mathrm{~S}, \mathrm{~T}$ & 4.833 & $\mathrm{~S}$ \\
\hline Benthic feeders & 0.229 & $\mathrm{U}, \mathrm{M}$ & 1.895 & $\mathrm{~S}, \mathrm{~T}$ & 5.935 & $\mathrm{~S}$ \\
\hline Flatfish & 0.151 & $\mathrm{U}, \mathrm{M}$ & & & 4.9 & $\mathrm{~S}$ \\
\hline Nekton feeders & 0.012 & $\mathrm{U}$ & 1.16 & $\mathrm{~S}, \mathrm{~T}$ & 4.34 & $\mathrm{~S}$ \\
\hline Carcasses & 1 & & - & & - & \\
\hline Organic matter & 183.884 & V & - & & - & \\
\hline Detritus & 2 & & - & & - & \\
\hline
\end{tabular}

A, Fonda Umani (1996); B, Heilmann and Richardson (1996); C, Fonda Umani et al. (2000); D, Danovaro et al. (2000); E, Fonda Umani and Beran (2003); F, Sorokin et al. (1999); G, Raicevich (2000); H, Da Ponte (2001); I, Brey (1990); J, Brey (2001); K, Moodley et al. (1998); L, Carrer and Opitz (1999); M, Pranovi et al. (2001); N, Caddy (1989); O, Paolini et al. (1998); P, Pellizzato et al. (1998); Q, Azzali et al. (2002); R, Cingolani et al. (2002); S, Pauly (1980); T, Froese and Pauly (2003); U, Relini et al. (1999); V, Salvi et al. (1999).

Table A3

Diet composition matrix for the functional groups of the Northern Adriatic Sea model. Predator groups are placed down the vertical axis and prey groups are along the horizontal axis; grey cells indicate values lower than $1 \%$.

\begin{tabular}{|c|c|c|c|c|c|c|c|c|c|c|c|c|c|c|c|c|c|}
\hline & Prey/predator & 2 & 3 & 4 & 5 & 6 & 7 & 8 & 9 & 10 & 11 & 12 & 13 & 14 & 15 & 16 & 17 \\
\hline 1 & Phytoplankton & 0.02 & 0.97 & 0.67 & & 0.05 & & & 0.60 & 0.60 & 0.60 & & 0.61 & & & & \\
\hline 2 & Bacterioplankton & 0.04 & 0.03 & 0.16 & & & & & 0.05 & 0.05 & 0.05 & & & & & & \\
\hline 3 & Microzooplankton & 0.05 & & 0.16 & & & & & 0.24 & 0.24 & 0.24 & & 0.20 & & & & \\
\hline 4 & Zooplankton & & & & & & 0.07 & & 0.10 & 0.10 & 0.10 & & 0.10 & & 0.01 & 0.10 & \\
\hline 5 & Meiobenthos & & & & 0.01 & 0.05 & 0.20 & 0.20 & & & & 0.02 & & & & & \\
\hline 6 & Macrobenthos herbivorous & & & & & & 0.06 & & & & & 0.01 & & 0.08 & 0.07 & 0.10 & \\
\hline 7 & Macrobenthos omnivorous & & & & & & 0.04 & & & & & 0.05 & & 0.14 & 0.10 & 0.08 & \\
\hline 8 & Macrobenthos detritivorous & & & & & & 0.16 & & & & & 0.45 & 0.06 & 0.18 & 0.44 & 0.45 & 0.08 \\
\hline 9 & Macrobenthos filter feeders & & & & & & 0.10 & & & & & 0.05 & 0.02 & 0.02 & 0.14 & 0.05 & \\
\hline 10 & Scallops (Pectinidae) & & & & & & & & & & & & & & 0.01 & & \\
\hline 11 & Clams (Veneridae) & & & & & & & & & & & & & & 0.01 & & \\
\hline 12 & Macrobenthos predator & & & & & & & & & & & 0.02 & 0.01 & 0.41 & 0.14 & 0.14 & 0.01 \\
\hline 13 & Planktivorous fish & & & & & & & & & & & & & 0.10 & 0.01 & 0.04 & 0.40 \\
\hline 14 & Cephalopods & & & & & & & & & & & & & 0.03 & 0.01 & & 0.17 \\
\hline 15 & Benthic feeders & & & & & & & & & & & & & & 0.01 & & 0.20 \\
\hline 16 & Flatfish & & & & & & & & & & & & & & & 0.01 & 0.03 \\
\hline 17 & Nekton feeders & & & & & & & & & & & & & & & & 0.10 \\
\hline 18 & Carcasses & & & & & & 0.25 & 0.05 & & & & 0.39 & & 0.03 & 0.06 & 0.03 & \\
\hline 19 & Organic matter & 0.89 & & & & & & & 0.01 & 0.01 & 0.01 & & & & & & \\
\hline 20 & Detritus & & & & 0.99 & 0.90 & 0.12 & 0.75 & & & & & & & & & \\
\hline
\end{tabular}

Table A4

References for the diet matrix.

\begin{tabular}{ll}
\hline Bacterioplankton & Fonda Umani and Beran (2003) \\
Microzooplankton & Fonda Umani and Beran (2003) \\
Zooplankton & Baamstedt and Karlson (1998) \\
Meiobenthos & Carrer and Opitz (1999) \\
Macrobenthos herbivorous & Fauchald and Jumars (1979), Carrer and Opitz (1999), Riedl (1992) \\
Macrobenthos omnivorous & Fauchald and Jumars (1979), Carrer and Opitz (1999), Riedl (1992) \\
Macrobenthos detritivorous & Fauchald and Jumars (1979), Carrer and Opitz (1999) Riedl (1992) \\
Macrobenthos filter feeder & Fauchald and Jumars (1979), Riedl (1992), Sorokin and Giovanardi (1995) \\
Scallops (Pectinidae) & Sorokin and Giovanardi (1995) \\
Clams (Veneridae) & Sorokin and Giovanardi (1995) \\
Macrobenthos predator & Fauchald and Jumars (1979), Froglia and Giannini (1989), Riedl (1992), Carrer and Opitz (1999) \\
Planktivorous fish & Demirhindi (1961), Tudela and Palomera (1997), Ticina et al. (2000) \\
Cephalopds & Castro and Guerra (1990), Pierce et al. (1994), CephBase (2006) \\
Benthic feeders & Giovanardi and Rizzoli (1984), Pinnegar and Polunin, (1999), Froese and Pauly (2003) \\
Flatfish & Giovanardi and Piccinetti (1981), Giovanardi and Piccinetti (1984), Froese and Pauly (2003) \\
Nekton feeders & Arias (1980), Pinnegar and Polunin (1999), Froese and Pauly (2003)
\end{tabular}


Table A5

Biomass export in terms of commercial catches $\left(1 \mathrm{~km}^{-2}\right)$ by the five main finishing activities identified in the study area; grey cells indicate values lower than $1 \mathrm{~kg}$.

\begin{tabular}{|c|c|c|c|c|c|c|c|}
\hline & Group name & Mid-water trawl & Hydraulic dredge & Rapido trawl (flatfish) & Rapido trawl (scallops) & Otter trawl & Total \\
\hline 1 & Phytoplankton & & & & & & \\
\hline 2 & Bacterioplankton & & & & & & \\
\hline 3 & Microzooplankton & & & & & & \\
\hline 4 & Zooplankton & & & & & & \\
\hline 5 & Meiobenthos & & & & & & \\
\hline 6 & Macrobenthos herbivorous & & & & & & \\
\hline 7 & Macrobenthos omnivorous & & & & & 0.015 & 0.015 \\
\hline 8 & Macrobenthos detritivorous & & & & & & \\
\hline 9 & Macrobenthos filter feeders & & & & & & \\
\hline 10 & Scallops (Pectinidae) & & & & 0.152 & & 0.152 \\
\hline 11 & Clams (Veneridae) & & 1.010 & & & & 1.010 \\
\hline 12 & Macrobenthos predator & & & & & & \\
\hline 13 & Planktivorous fish & 0.444 & & & & & 0.444 \\
\hline 14 & Cephalopods & & & & & 0.078 & 0.078 \\
\hline 15 & Benthic feeders & & & & & 0.036 & 0.036 \\
\hline 16 & Flatfish & & & 0.023 & & & 0.023 \\
\hline 17 & Nekton feeders & & & & & 0.003 & 0.003 \\
\hline 18 & Carcasses & & & & & & \\
\hline 19 & Organic Matter & & & & & & \\
\hline \multirow[t]{2}{*}{20} & Detritus & & & & & & \\
\hline & Sum & 0.444 & 1.010 & 0.023 & 0.152 & 0.132 & 1.761 \\
\hline
\end{tabular}

established which each represent a composite of species in various functional groups (Table A1). In relation to the available data, the meiofauna was grouped into a single node, whereas macrobenthic species were grouped mainly according to five trophic nodes. Moreover, due to their importance as target species for local fishing, two groups of bivalve molluscs (scallops and clams targeted by rapido trawling and hydraulic dredging, respectively) were separately defined in order to better describe the ecological effects of these two fleets. Biomass estimates were taken from experimental studies carried out in the study area during the research activities conducted by the Environmental Science Department of the University of Venice (Table A2; Raicevich, 2000, 2003; Da Ponte, 2001; ICRAM, 2006). Vital rate parameters and estimates of feeding by and on these nodes were obtained by literatures values (Tables A2-A4).
The nekton compartment was characterized by five nodes, defined according to both ecological and fisheries features. The model therefore accounted for pelagic and benthic fish, cephalopods and flatfish (all targeted by specific fishing activities) and nekton feeders to represent the top predators. Biomass estimates were obtained both by field surveys carried out by in the context of the national programs for the stock assessment and on-board surveys (Table A2; Relini et al., 1999). Vital rate parameters and estimates of feeding by and on these nodes were obtained both from studies conducted in the region and from more general literatures sources (Tables A2-A4).

To better reflect reality and to help in the model balancing, elements of the microbial loop, such as the dissolved organic carbon (modelled by using suspended organic matter as proxy) and car-

Table A6

Biomass export in terms of discards $\left(\mathrm{t} \mathrm{km}^{-2}\right)$ by the five main fishing activities identified in the study area; grey cells indicate values lower than $1 \mathrm{~kg}$.

\begin{tabular}{|c|c|c|c|c|c|c|c|}
\hline & Group name & Mid-water trawl & Hydraulic dredge & Rapido trawl (flatfish) & Rapido trawl (scallops) & Otter trawl & Total \\
\hline 1 & Phytoplankton & & & & & & \\
\hline 2 & Bacterioplankton & & & & & & \\
\hline 3 & Microzooplankton & & & & & & \\
\hline 4 & Zooplankton & & & & & & \\
\hline 5 & Meiobenthos & & & & & & \\
\hline 6 & Macrobenthos herbivorous & & 0.075 & 0.008 & 0.007 & 0.014 & 0.104 \\
\hline 7 & Macrobenthos omnivorous & & 0.115 & 0.088 & 0.011 & 0.035 & 0.249 \\
\hline 8 & Macrobenthos detritivorous & & 0.003 & & & & 0.003 \\
\hline 9 & Macrobenthos filter feeders & & 0.197 & 0.004 & & & 0.202 \\
\hline 10 & Scallops (Pectinidae) & & & & & & \\
\hline 11 & Clams (Veneridae) & & & & & & \\
\hline 12 & Macrobenthos predator & & 0.002 & 0.020 & 0.006 & 0.001 & 0.030 \\
\hline 13 & Planktivorous fish & & & & & 0.017 & 0.017 \\
\hline 14 & Cephalopods & & & & & & \\
\hline 15 & Benthic feeders & & & 0.002 & & 0.004 & 0.005 \\
\hline 16 & Flat fish & & & 0.001 & & & 0.001 \\
\hline 17 & Nekton feeders & & & & & & \\
\hline 18 & Carcasses & & & & & & \\
\hline 19 & Organic matter & & & & & & \\
\hline \multirow[t]{2}{*}{20} & Detritus & & & & & & \\
\hline & Sum & & 0.392 & 0.124 & 0.024 & 0.071 & 0.611 \\
\hline
\end{tabular}

Estimates of the discarded fraction for each functional group were obtained by on-board surveys (Pranovi et al., 2001; Raicevich, 2003). 
casses produced by the discarding activities, were included in the model.

In comparison with the other parameters, the diet matrix was considered the most uncertain aspect of the model and thus was adjusted iteratively by using the Automatic Mass Balance Procedure (Kavanagh et al., 2004). During the balancing process, the diet matrix was slightly modified to avoid inconsistent solutions of the energy budget when the parameters are randomly changed around the nominal value (Christensen et al., 2000; Christensen and Walters, 2000). The small differences between initial values and those obtained after the iterative adjustments affirmed the relatively good initial estimates included in the diet matrix. All the main fishing activities (mid-water trawling, otter trawling, rapido trawling and hydraulic dredging) have been explicitly included in the model. Official landings statistics from 1990 to 2000 were available from the Chioggia fish market and the Fishermen Consortium for the clam exploitation (COGEVO). The mean value was calculated for the 1997-2000 period and used for the model (Table A5). Moreover, catch data were corrected by considering estimates of unreported/illegal catches (Mattei and Pellizzato, 1996; Raicevich, 2000; Giovanardi, unpublished data), by extending to the official catches the ratio observed during on-board surveys (Table A6).

\section{References}

Artegiani, A., Bregant, D., Paschini, E., Pinardi, N., Raicich, F., Russo, A., 1997a. The Adriatic Sea general circulation. Part I: Air-sea interactions and water mass structure. Journal of Physical Oceanography 27, 1492-1514.

Artegiani, A., Bregant, D., Paschini, E., Pinardi, N., Raicich, F., Russo, A., 1997b. The Adriatic Sea general circulation. Part II: Baroclinic circulation structure. Journa of Physical Oceanography 27, 1515-1532.

Azam, F., Fenchel, T., Field, J.G., Gray, J.S., Meyer-Reil, L.A., Thingstad, F., 1983. The ecological role of water-column microbes in the sea. Marine Ecology Progress Series 10, 257-263.

Baird, S.F., 1873. Natural history of some of the more important food-fishes of the south shore of New England. In: Report on the Condition of the Sea Fisheries of the South Coast of New England in 1871 and 1872. Rep. Commissioner U.S Comm. Fish. Fisheries, Pt. I, pp. 228-235.

Bax, N.J., 1991. A comparison of the fish biomass flow to fish, fisheries, and mammals on six marine ecosystems. ICES Marine Science Symposium 193, 217-224.

Berkes, F., Colding, J., Folke, C. (Eds.), 2002. Navigating Social-Ecological Systems: Building Resilience for Complexity and Change. Cambridge University Press, Cambridge.

Bombace, G., 2002. Riflessioni sulla pesca, biodiversità ed aree marine protette. Biologia Marina Mediterranea 9, 48-70.

Bosc, E., Bricau, A., Antoine, D., 2004. Seasonal and interannual variability in alga biomass and primary production in the Mediterranean Sea, as derived from 4 years of SeaWiFS observations. Global Biogeochemical Cycles 18 (GB1005), 17 pp.

CBD (Convention on Biological Diversity), 2004. Available from: <www.biodiv.org/ programmes/cross-cutting/ecosystem/>

Christensen, V., Pauly, D., 1992. ECOPATH II - a software for balancing steady-state models and calculating network characteristics. Ecological Modelling 61, 169185.

Christensen, V., Pauly, D. (Eds.), 1993. Trophic Models of Aquatic Ecosystems, vol. 26. ICLARM, Manila, Philippines, $390 \mathrm{pp}$.

Christensen, V., Walters, C.J., 2000. Ecopath and Ecosim: methods, capabilities and limitations. In: Pauly, D., Pitcher, T.J. (Eds.), Methods for Assessing the Impact of Fisheries on Marine Ecosystems of the North Atlantic. Fishery Center Research Report, vol. 8, pp. 79-105.

Christensen, V., Walters, C., 2004. Ecopath with Ecosim: methods, capabilities and limitations. Ecological Modelling 172, 109-139.

Christensen, V., Walters, C., Pauly, D., 2004. Ecopath with Ecosim: A User's Guide. Fisheries Centre of University of British Columbia, Vancouver, Canada, $154 \mathrm{pp}$

Cohen, E.B., Grosslein, M.D., Sissenwine, M.P., 1982. Energy budget of Georges Bank. Canadian Special Publication Fishery and Aquatic Science 59, 95-107.

Coll, M., Santojanni, A., Palomera, I., Tudela, S., Arneri, E., 2007. An ecological model of the Northern and Central Adriatic Sea: analysis of ecosystem structure and fishing impacts. Journal of Marine Systems 67, 119-154.

Cury, P., Shannon, L.J., Roux, J.-P., Daskalov, G., Jarre, A., Pauly, D., Moloney, C.L., 2005. Trophodynamic indicators for an ecosystem approach to fisheries. ICES Journal of Marine Science 62, 430-442.

Dayton, P.K., Thrush, S.F., Agardy, M.T., Hofman, R.J., 1995. Environmental effects of fishing. Aquatic Conservation: Marine and Freshwater Ecosystems 5, 205-232.

de Ruiter, P.C., Neutel, A., Moore, J.C., 1995. Energetics, patterns of interaction strengths, and stability in real ecosystems. Science $269,1257-1260$.
Duffy, J.E., 2006. Biodiversity and functioning of seagrass ecosystems. Marine Ecology Progress Series 311, 233-250.

FAO, 2003. The Ecosystem Approach to Fisheries. FAO Technical Guidelines for Responsible Fisheries, 4 (Suppl. 2), FAO, Rome, 112 pp.

Fath, B.D., Killian, M.G., 2007. The relevance of ecological pyramids in community assemblages. Ecological Modelling 208, 286-294.

Fonda Umani, S., Franco, P., Ghirardelli, E., Malej, A., 1992. Outline of oceanography and the plankton of the Adriatic Sea. In: Colombo, G., Ferrari, I., Ceccherellie, V.U., Rossi, R. (Eds.), Marine Eutrophication and Population Dynamics. Olsen \& Olsen, Fredensborg, pp. 347-365.

Frank, K.T., Petrie, B., Shackell, N.L., Choi, J.S., 2006. Reconciling differences in trophic control in mid-latitude marine ecosystems. Ecology Letters 9, 10961105.

Frank, K.T., Petrie, B., Shackell, N.L., 2007. The ups and downs of trophic control in continental shelf ecosystems. Trends in Ecology and Evolution 22, 236-242.

Gamulin-Brida, H., 1974. Biocoenoeses benthiques de la Mer Adriatique. Acta Adriatica 15, 5-99.

Giovanardi, O., Pranovi, F., Franceschini, G., 1998. "Rapido" trawl-fishing in the Northern Adriatic: preliminary observations on effects on macrobenthic communities. Acta Adriatica 39, 37-52.

Grosslein, M., Langton, R., Sissenwine, M.P., 1980. Recent fluctuations in pelagic fish stocks of the northwest Atlantic, Georges Bank region, in relation to species interactions. Rapports et Proces-Verbaux des Reunions du Conseil International pour l'Exploration de la Mer 177, 374-404.

Gunderson, L.H., Holling, C.S. (Eds.), 2002. Panarchy: Understanding Transformations in Human and Natural Systems. Island Press, Washington, DC.

Holling, C.S., 1996. Engineering resilience versus ecological resilience. In: Schulze P.C. (Ed.), Engineering within Ecological Constraints. National Academy Press, Washington, DC

Holling, C.S., Schindler, D.W., Walker, B.W., Roughgarden, J., 1995. Biodiversity in the functioning of ecosystems: an ecological synthesis. In: Perrings, C.A., Maler, K.-G., Folke, C., Holling, C.S., Jansson, B.-O. (Eds.), Biodiversity Loss. Economic and Ecological Issues. Cambridge University Press, Cambridge, UK, pp. 44-83.

Hunt Jr., G.L., Megrey, B.A., 2005. Comparison of the biophysical and trophic characteristics of the Bering and Barents Seas. ICES Journal of Marine Science $62,1245-1255$.

Hyrenbach, K.D., Forney, K.A., Dayton, P.K., 2000. Marine protected areas and ocean basin management. Aquatic Conservation: Marine and Freshwater Ecosystems $10,437-458$.

ICRAM, 2006. Valutazione della sostenibilità di nuove strategie co-gestionali di pesca mediante un approccio ecosistemico. Relazione finale SosPEco PR/271, Istituto Centrale Ricerca Applicata al Mare, Chioggia, 145 pp.

Jones, J.B., 1992. Environmental impact of trawling on the sea bed: a review. New Zealand Journal of Marine Freshwater Research 26, 59-67.

Jorgensen, S.E., 1992. Exergy and ecology. Ecological Modelling 63, 185-214.

Kaiser, M.J., de Groot, S.J., 2000. Effects of Fishing on Non-target Species and Habitats. Blackwell Science.

Kasperson, J.X., Kasperson, R.E. (Eds.), 2001. Global Environmental Risk. United Nations University Press/Earthscan, London.

Kelleher, K., 2005. Discards in the World's Marine Fisheries. An update. FAO Fisheries Technical Paper. No. 470. Rome, FAO, $131 \mathrm{pp}$

Libralato, S., Pranovi, F., Raicevich, S., Giovanardi, O., 2004. Mixed trophic impact and transfer efficiency as indicators of species' role and ecosystem state. Biologia Marina Mediterranea 11, 255-264.

Libralato, S., Christensen, V., Pauly, D., 2006. A method for identifying keystone species in food web models. Ecological Modelling 195 (3-4), 153-171.

Libralato, S., Coll, M., Tutela, S., Palomera, I., Pranovi, F., 2008. Quantifying ecosystem overfishing: theoretical development and application of a new index of fisheries' impact on marine trophic webs. Marine Ecology Progress Series 355, 107-129.

Link, J.S., 2002. Ecological considerations in fisheries management: when does it matter? Fisheries 27, 10-17.

Link, J.S., 2005. Translation of ecosystem indicators into decision criteria. ICES Journal of Marine Science 62, 569-576.

Link, J.S., Griswold, C.A. Methratta, E.M., Gunnard, J. (Eds.), 2006. Documentation fo the Energy Modeling and Analysis eXercise (EMAX). Northeast Fisheries Science Center Reference Document, 06-15, 166 pp.

Malanotte Rizzoli, P., Bergamasco, A., 1983. The dynamics of the coastal region of the northern Adriatic Sea. Journal of Physical Oceanography 13, 1105-1130.

McCann, K.S., Hastings, A., Huxel, G.R., 1998. Weak trophic interactions and the balance of nature. Nature 395, 794-797.

Moloney, C.L., Jarre, A., Arancibia, H., Bozec, Y.-M., Neira, S., Roux, J.-P., Shannon, L.J. 2005. Comparing the Benguela and Humboldt marine upwelling ecosystems with indicators derived from inter-calibrated models. ICES Journal of Marine Science 62, 493-502.

Monaco, M.E., Ulanowicz, R.E., 1997. Comparative ecosystem trophic structure of three U.S. mid-Atlantic estuaries. Marine Ecology Progress Series 161, 239-254.

Murawski, S.A., 2000. Definitions of overfishing from an ecosystem perspective. ICES Journal of Marine Science 57, 649-658.

Neutel, A.-M., Heesterbeek, J.A.P., van de Koppel, J., Hoenderboom, G., Vos, A., Kaldeway, C., Berendse, F., de Ruiter, P.C., 2007. Reconciling complexity with stability in naturally assembling food webs. Nature 449, 599-602.

Odum, E.P., 1969. The strategy of ecosystem development. Science 164, 262-270.

O'Reilly, J.E., Zetlin, C., 1998. Seasonal, Horizontal, and Vertical Distribution of Phytoplankton Chlorophyll a in the Northeast U.S. Continental Shelf Ecosystem. NOAA Technical Report NMFS 139, 120 pp. 
Ortiz, M., Wolff, M., 2002. Trophic models of four benthic communities in Tongoy Bay (Chile): comparative analysis and preliminary assessment of management strategies. Journal of Experimental Marine Biology and Ecology 268, 205-235.

Paine, R.T., 1969. A note on trophic complexity and community stability. American Naturalist 103, 91-93.

Patrìcio, J., Ulanowicz, R., Pardal, M.A., Marques, J.C., 2006. Ascendency as ecological indicator for environmental quality assessment at the ecosystem level: a case study. Hydrobiologia 555, 19-30.

Pauly, D., Christensen, V., 1995. Primary production required to sustain global fisheries. Nature 374, 255-257.

Pauly, D., Christensen, V., Dalsgaard, J., Froese, R., Torres, F.J., 1998. Fishing down marine food webs. Science 279, 860-863.

Pauly, D., Christensen, V., Guenette, S., Pitcher, T.J., Sumaila, U.R., Walters, C., Watson, R., Zeller, D., 2002. Towards sustainability in world fisheries. Nature 418, 689-695.

Pérès, J.M., Picard, J., 1964. Nouveau manuel de bionomie bentique de la Mer Mediterranee. Recueil des Travaux de la Station Marine d'Endoume Bolletin 31, $1-137$

Pérez-España, H., Arreguín-Sánchez, F., 1999. A measure of ecosystem maturity. Ecological Modelling 2, 129-135.

Pickitch, E.K., Santora, C., Babcock, E.A., Bakun, A., Bonfil, R., Conover, D.O., Dayton, P., Doukakis, P., Fluharty, D., Heneman, B., Houde, E.D., Link, J., Livingston, P.A., Mangel, M., McAllister, M.K., Sainsbury, K.J., Pope, J., 2004. Ecosystem-based fishery management. Science 305, 346-347.

Pinardi, N., Arneri, E., Crise, A., Ravaioli, M., Zavatarelli, M., 2006. The physical, sedimentary and ecological structure and variability of shelf areas in the Mediterranean Sea. In: Robinson, A.R., Brink, K. (Eds.), The Sea, the Global Coastal Ocean Interdisciplinary Regional Studies and Syntheses, vol. 14B. Harvard University Press, Cambridge, USA (Chapter 32).

Poppe, L.J., Paskevich, V.F., Williams, S.J., Hastings, M.E. Kelly, J.T., Belknap, D.F. Ward, L.G., FitzGerald, D.M., Larsen, P.F., 2003. Surficial Sediment Data from the Gulf of Maine, Georges Bank, and Vicinity: A GIS Compilation. US Geological Survey Open-File Report 03-001.

Power, M.E., Tilman, D., Ester, J.A., Menge, B.A., Bond, W.A., Mills, L.S., Daily, G., Castilla, J.C., Lubchenco, J., Paine, R.T., 1996. Challenge in the question for keystones. Bioscience 46, 609-620.

Raffaelli, D., 2006. Biodiversity and ecosystem functioning: issues of scale and trophic complexity. Marine Ecology Progress Series 311, 285-294.

Revelante, N., Gilmartin, M., 1983. The phytoplankton of the Adriatic Sea: community structure and characteristics. Thalassia Jugoslavica 19, 303-318.

Scheffer, M., Carpenter, S., Foley, J.A., Folke, C., Walzer, B., 2001. Catastrophic shifts in ecosystems. Nature 413, 591-596.

Sissenwine, M.P., Cohen, E.B., Grosslein, M.D., 1984. Structure of the Georges Bank ecosystem. Rapports et Proces-Verbaux des Reunions du Conseil International pour l'Exploration de la Mer 183, 243-254

Strong, D.R., 1992. Are trophic cascades all wet? Differentiation and donor-control in speciose ecosystems. Ecology 73, 747-754.

Turley, C.M., 1999. The changing Mediterranean Sea - a sensitive ecosystem? Progress in Oceanography 44, 387-400.

Ulanowicz, R.E., 1986. Growth and Development: Ecosystem Phenomenology. Springer, New York. 203 pp

Ulanowicz, R.E., 1997. Ecology, the Ascendent Perspective. Complexity in the Ecological Systems Series. Columbia University Press, New York.

Ulanowicz, R.E., Puccia, C.J., 1990. Mixed trophic impacts in ecosystems. Coenoses 5. $7-16$.

Ulanowicz, R.E., Norden, J.S., 1990. Symmetrical overhead in flow and networks. International Journal of Systems Science 21 (2), 429-437.

Ulanowicz, R.E., Wulff, F., 1991. Comparing ecosystems structures: the Chesapeake Bay and the Baltic Sea. In: Cole, J., Lovett, G., Findlay, S. (Eds.), Comparative Analyses of Ecosystems: Patterns, Mechanisms and Theories. Springer-Verlag, Berlin, Germany, pp. 140-166.

USOC (U.S. Ocean Commission), 2004. An Ocean Blueprint for the 21st Century: Final Report of the U.S. Commission on Ocean Policy. Washington, DC. Available from: <http://www.oceancommission.gov/documents/prepub_report/welcome. html\#final/>.

Vasconcellos, M., Mackinson, S., Sloman, K., Pauly, D., 1997. The stability of trophic mass-balance models of marine ecosystems a comparative analysis. Ecological Modelling 100, 125-134.

Walters, C.J., Christensen, V., Pauly, D., 1997. Structuring dynamic models of exploited ecosystems from trophic mass-balance assessments. Review in Fish Biology and Fishery 7, 139-172.

WSSD, 2002. Available from: <http://www.worldsummit2002.org/>

Wolff, M., 1994. A trophic study for Tongoy Bay - a system exposed to suspended scallop culture (Northern Chile). Journal Experimental Marine Biology Ecology 182, 149-168.

Wolff, M., Hartmann, H.J., Koch, V., 1996. A pilot trophic model for Golfo Dulce, a fjord-like tropical embayment, Costa Rica. Revista de Biología Tropical 44, 215 231

Wulff, F., Ulanowicz, R.E., 1989. A comparative anatomy of the Baltic Sea and Chesapeake ecosystems. In: Wulff, F., Field, J.G., Mann, K.H. (Eds.), Network Analysis in Marine Ecology. Methods and Applications. Springer-Verlag, Berlin, Germany, pp. 232-256.

Zajac, R.N., 1999. Understanding the seafloor landscape in relation to assessing and managing impacts on coastal environments. In: Gray, J.S., Ambrose, W., Jr., Szaniawska, A. (Eds.), Biogeochemical Cycling and Sediment Ecology. Kluwer Publishing, Dordrecht, pp. 211-227.

\section{Appendix references}

Arias, A., 1980. Crecimiento, regimen alimentario y reproduccion de la dorada (Sparus aurata L) y del robalo (Dicentrarchus labrax L.) en los esteros de Cadiz. Investigacion Pesquera 44, 59-83.

Azzali, M., De Felice, A., Luna, M., Cosimi, G., Parmiggiani, F., 2002. The state of the Adriatic Sea centered on the small pelagic fish populations. P.S.Z.N. Marine Ecology 23, 78-91.

Baamstedt, U., Karlson, K., 1998. Euphausiid predation on copepods in coastal waters of the Northeast Atlantic. Marine Ecology Progress Series 172, 149-168.

Brey, T., 1990. Estimating productivity of macrobenthic invertebrates from biomass and mean individual weight. Meeresforschung 32, 329-343.

Brey, T., 2001. Population dynamics in benthic invertebrates. A Virtual Handbook, http://www.awi-remerhaven.de/Benthic/Ecosystem/FoodWeb/Handbook/ main.html. Alfred Wegener Institute for Polar and Marine Research, Germany.

Caddy, J.F. (Ed.), 1989. A perspective on the population dynamics and assessment of scallop fisheries, with special reference to the sea scallop, Placopecten magellanicus Gmelin. In: Marine Invertebrate Fisheries: Their Assessment and Management. Wiley, New York, pp. 559-589.

Carrer, S., Opitz, S., 1999. Trophic network model of a shallow water area in the northern part of the Lagoon of Venice. Ecological Modelling 124, 193-219.

Castro, B.G., Guerra, A., 1990. The diet of Sepia officinalis (Linnaeus, 1758) and Sepia elegans (D’Orbigny, 1835) (Cephalopoda, Sepioidea) from the Ría de Vigo (NW Spain). Scientia Marina 54, 375-388.

CephBase, 2006. Available from: <http://www.cephbase.org>.

Cingolani, N., Santojanni, A., Arneri, E., Belardinelli, A., Giannetti, G., Colella, S., Donato, F., 2002. Stock assessment of sardine (Sardina pilchardus, Walb) in the Adriatic Sea. Biologia Marina Mediterranea 9, 82-88.

Danovaro, R., Gambi, C., Manini, E., Fabiano, M., 2000. Meiofauna response to a dinamic river plume front. Marine Biology 137, 359-370.

Da Ponte, F., 2001. La pesca a strascico come fattore di disturbo ecologico in Laguna di Venezia e in Alto Adriatico. MSc thesis, Università di Ca' Foscari, Venice, Italy, unpublished.

Demirhindi, U., 1961. Nutrition of the sardine (Sardina pilchardus Walb.). In: Proceedings and Technical Papers of the General Fisheries Council for the Mediterranean, vol. 6, pp. 253-259.

Fauchald, K., Jumars, P.A., 1979. The diet of worms: a study of polychaete feeding guilds. Oceanography and Marine Biology Annual Review 17, 193-284.

Fonda Umani, S., 1996. Pelagic production and biomass in the Adriatic Sea. Scientia Marina 60, 65-77.

Fonda Umani, S., Beran, A., 2003. Seasonal variations in the dynamics of microbial plankton communities: first estimates from experiments in the Gulf of Trieste, N Adriatic Sea. Marine Ecology Progress Series 247, 1-16.

Fonda Umani, S., Beran, A., Cabrini, M., Cataletto, B., Del Negro, P., De Vittor, C., 2000. Prime misure dei principali flussi energetici nel comparto pelagico del Golfo di Trieste: Autunno 1998. Biologia Marina Mediterranea 7, 46-60.

Froese, R., Pauly, D., 2003. FishBase. World Wide Web electronic publication. http:// www.fishbase.org, version 11/2001.

Froglia, C., Giannini, S., 1989. Field observations on diel rhythms in catchability and feeding of Squilla mantis (L.) (Crustacea, Stomatopoda) in the Adriatic Sea. In: Ferrero, E.A. (Ed.), Biology of Stomatopods. Selected Symposia and Monographs U.Z.I., vol. 3.

Giovanardi, O., Piccinetti, C., 1981. Biology and fishery of the yellow sole, Solea lutea (Risso) 1810, in the western Adriatic Sea. FAO Fisheries Report 253, pp. 101112.

Giovanardi, O., Piccinetti, C., 1984. Biology and fishery aspects of the scaldfish Arnoglossus laterna (Walbaum) 1792, in the Adriatic Sea. FAO Fisheries Report 290, pp. 161-166.

Giovanardi, O., Rizzoli, M., 1984. Biological data, collected during the Pipeta expeditions, on the whiting, Merlangius merlangus (L.) in the Adriatic Sea. FAO Fisheries Report 290, pp. 149-153.

Heilmann, J.P., Richardson, K., 1996. Phytoplankton distribution and activity in the northern Adriatic Sea. In: Proceedings of the Workshop Physical and Biogeochemical Processes in the Adriatic Sea. Portonovo (Ancona) Italy. Ecosystem research report, vol. 32, 23-27 April 1996, pp. 347-362.

ICRAM, 2006. Valutazione della sostenibilità di nuove strategie co-gestionali di pesca mediante un approccio ecosistemico. Relazione finale SosPEco PR/271, 145 pp.

Kavanagh, P., Newlands, N., Christensen, V., Pauly, D., 2004. Automated parameter optimization for Ecopath ecosystem models. Ecological Modelling 172, 141150.

Mattei, N., Pellizzato, M., 1996. A population study on three stocks of a commercial Adriatic pectinid (Pecten jacobaeus). Fisheries Research 26, 49-65.

Moodley, L., Heip, C.H.R., Middelburg, J.J., 1998. Benthic activity in consumption, macro- and meiofauna dynamics. Journal of Sea Research 40, 263-280.

Paolini, M., Piccinetti, C., Manfrin, G., 1998. Stock di vongole nel compartimento marittimo di Ravenna. Biologia Marina Mediterranea 5, 395-400.

Pauly, D., 1980. On the interrelationships between natural mortality, growth parameters, and mean environmental temperature in 175 fish stocks. Journal du Conseil, Conseil Intérnational pour l'Exploration de la Mer 39, 175-192.

Pellizzato, M., Cordonello, M., Folin, D., Grim, F., Libralato, M., Nesto, N., Rocco, R., Trigg, R.E., Vendramini, A., 1998. Sperimentazione della gestione dei banchi Naturali di molluschi bivalvi della specie Chamelea gallina nei compartimenti marittimi di Venezia e Monfalcone. Biologia Marina Mediterranea 5, 385394 
Pierce, G.J., Boyle, P.B., Hastie, L.C., Santos, M.B., 1994. Diets of squid Loligo forbesi and Loligo vulgaris in the northeast Atlantic. Fisheries Research 21, 149-163.

Pinnegar, J.K., Polunin, N.V.C., 1999. Contributions of stable-isotope data to elucidating food webs of Mediterranean rocky littoral fishes. Oecologia 122 399-409.

Pranovi, F., Raicevich, S., Franceschini, G., Torricelli, P., Giovanardi, O., 2001. Discard analysis and damage to non-target species in the Rapido trawl fishery. Marine Biology 139, 863-875.

Raicevich, S., 2000. La pesca con il rapido in nord Adriatico: effetti sulle comunità bentoniche ed implicazioni gestionali. MSc thesis, Università Ca' Foscari, Venice, Italy, unpublished.

Raicevich, S., 2003. Assessment of ecological disturbance in marine environments. $\mathrm{PhD}$ thesis, Università Ca' Foscari,Venice, Italy, unpublished.

Relini, G., Bertrand, J., Zamboni, A. (Eds.), 1999. Sintesi delle conoscenze sulle risorse da pesca dei fondali del Mediterraneo Centrale (Italia e Corsica). Biologia Marina Mediterranea 6, 878 .
Riedl R., 1992. Fauna e flora del Mediterraneo. Ed. Muzzio, Massa Carrara.

Salvi, C., Fonda Umani, S., Cok S., 1999. Contribution of phytoplankton to Particulate Organic Carbon in the Gulf of Trieste (Northern Adriatic Sea). Annals for Istrian and Mediterranean Studies, 13/98.

Sorokin, Y.I., Giovanardi, O., 1995. Trophic characteristics of the Manila clam (T philippinarum Adams \& Reeve, 1850). ICES Journal of Marine Science 52, 853 862.

Sorokin, Y.I., Sorokin, P.Y., Ravagnan, G., 1999. Analysis of lagoonal ecosystems in the Po river delta associated with intensive aquaculture. Estuarine, Coastal and Shelf Science 48, 325-341.

Ticina, V., Vidjak, O., Kacic, I., 2000. Feeding of adult sprat, Sprattus sprattus during spawning season in the Adriatic Sea. Italian Journal of Zoology 67, 307-311.

Tudela, S., Palomera, I., 1997. Trophic ecology of European anchovy Engraulis encrasicolus in the Catalan Sea (Northwest Mediterranean). Marine Ecology. Progress Series 160, 121-134. 